\title{
The Waiting Period of Initial Public Offerings
}

\author{
Hugh M. J. Colaco* \\ Aston Business School \\ Birmingham B4 7ET \\ United Kingdom \\ +44 (0)1212043193 \\ h.colaco@aston.ac.uk \\ Amedeo De Cesari \\ Alliance Manchester Business School \\ Manchester M15 6PB \\ United Kingdom \\ +44 (0)161306 6403 \\ amedeo.decesari@manchester.ac.uk \\ Shantaram P. Hegde \\ University of Connecticut \\ Storrs, CT 06269, USA \\ +18604865135 \\ shegde@business.uconn.edu
}

\begin{abstract}
The length of time it takes an IPO firm to go public (called "waiting period") reflects multiple layers of scrutiny from underwriters, auditors, venture capitalists, institutional investors, and regulators. Accordingly, we show that the waiting period is a good barometer of ex ante uncertainty about future cash flows and that it has predictive power after the firm goes public. We find that firms marked by short waiting periods experience lower underpricing and less uncertainty and superior stock/operating performance in the aftermarket. We also report that smaller firms are taking longer to go public after Sarbanes-Oxley, thus providing justification for the 2012 JOBS Act.
\end{abstract}

Keywords: initial public offering; waiting period; underpricing; ex ante uncertainty; stock performance; operating performance

JEL Classification: G30; G32

*Corresponding author. We thank two anonymous referees, two Associate Editors, Chris Adcock (the Editor), Frank D’Souza, Jay Ritter, and conference participants at the 2010 Financial Management Association meeting (New York, USA), 2011 India Finance Conference (Indian Institute of Management, Bangalore, India), 2012 European Financial Management Association meeting (Istanbul, Turkey), 2012 Frontiers of Finance Conference (Warwick Business School, UK), and 2012 India Finance Conference (Indian Institute of Management, Calcutta, India) for helpful comments. 


\section{Introduction}

Why do some firms take 226 days to clear the registration process and go public whereas others manage to do so in just 36 days ? $^{1}$ In this paper, we examine the determinants of the waiting period, defined as the number of days spent in registration from the date of the initial prospectus to the final offering of new shares to public investors. Our basic intuition is that IPO firms that are able to pass multiple rounds of scrutiny by large institutional investors, regulators, underwriters, auditors, listing exchanges, and venture capitalists within a short waiting period should have less uncertainty and information asymmetry about future cash flows, and be associated with better performance. Accordingly, we hypothesize that going-public firms marked by short registration periods would experience lower underpricing and less uncertainty and superior stock/operating performance in the aftermarket.

A short waiting period is important for a new firm since its business model, product, and services become very visible after the initial filing of the prospectus. Significant delays in going public would increase the likelihood that competitors would siphon away the capital that the firm would like to access, which could result in a withdrawal/postponement of the IPO - undesirable since only $10 \%$ of withdrawn issuers successfully go public a second time (Dunbar and Foerster 2008). Taking a firm public quickly is in the underwriter's interest too as it signals that the underwriter is able to convince institutional investors to come on board fairly quickly, thus protecting and enhancing underwriter reputation. It also frees up underwriter resources more quickly to focus on other equity/debt offerings. Further, market conditions can worsen overnight as evidenced by the crash of the internet bubble in 2000. Our data shows that of the 6588 firms to file for an IPO in the United States (U.S.) during 1986-2011, 4947 firms ended up going public (a two-thirds success rate). However, of the 28 firms to file in August 2000 (the final month of 
the internet bubble, according to Lowry, Officer, and Schwert (2010)), only 14 firms proceeded to go public (a success rate of half).

Based on a large sample of 4763 completed initial public offerings (IPOs) in the U.S. over 1986-2011, we find that ex ante uncertainty, legislation/regulatory issues, competition, efficiency, and industry/market conditions influence the waiting period. Specifically, higher underwriter/auditor reputation and greater institutional demand as reflected in the price update reduce ex ante uncertainty which results in lower waiting periods. However, greater ex ante uncertainty as reflected in large price updates (those exceeding $20 \%$ in either direction), the number of amendments, and volatility of industry returns results in longer waiting periods.

Further, the dispassionate evaluation of regulatory agencies serves to mitigate conflicts of interest, strengthen investor protection, and improve disclosure practices of going-public firms. In this connection, we find that the passage of Sarbanes-Oxley Act (SOX) Act in 2002 in the wake of a sharp increase in financial scandals has significantly increased the length of the waiting period, especially for smaller firms, which somewhat justifies the passing of the Jumpstart Our Business Startups (JOBS) Act in April 2012, designed to make the registration process easier for smaller IPOs.

Our results also show that hiring a large number of co-managers results in fast-moving IPOs, but when underwriters are busy taking several firms public at the same time, the waiting period for a given firm increases suggesting that inefficiencies may creep in. A firm tends to go public more quickly if it is a pioneer, a technology firm, and during favorable industry/market conditions. Our analysis extends Bouis (2009) who finds that the instantaneous probability of going public on NASDAQ over the next week (the IPO hazard rate) increases with the level of 
the aggregate market valuation, and decreases with the time-varying weekly market index return and the volatility of the weekly market index returns.

If the waiting period adequately captures ex ante uncertainty, this should be reflected in the after-market. We provide overwhelming evidence that this is the case. Specifically, we find that fast-moving IPOs have:- i) lower underpricing (except during the bubble period), ii) lower stock return volatility as captured by the market model root-mean-square error for the following four periods (based on trading days) after the IPO:- +21 to +79 ; +21 to +142 ; +21 to +205 ; +21 to +268, iii) lower standard deviation in earnings per share (EPS) and long-term growth forecasts for 90-, 180-, 270-, and 360-calendar days following the IPO. We also report better stock performance for up to three years after the IPO based on buy-and-hold abnormal returns, the 3factor model of Fama and French (1993), and 4-factor model of Carhart (1997), and superior operating performance using four measures for up to three years post-IPO for IPOs with short waiting periods.

Our analysis distinguishes between the primary decision to take a private firm public (and file the preliminary registration statement with the SEC) and the subsequent decision to finalize the offer price and time. Draho (2000), Benninga, Helmantel, and Sarig (2005) and Pastor and Veronesi (2005) use real option models to study the first decision - the option of a private firm to go public to raise funds to exploit its investment opportunities. To address the second decision, Busaba (2006) develops a model of bookbuilding that recognizes the flexibility that the goingpublic firm enjoys to withdraw its offering in the face of weak investor interest. Bouis (2009) extends Busaba's model of the withdrawal option by accounting for the issuer's option to wait to go public until general stock market conditions turn favorable. 
Chen and Cotter (2002) assume that if the underwriter receives positive information from investors or the market about the quality of the IPO, the issue will be offered as soon as possible. In this scenario, underpricing will be greater since it is a reward for providing positive information during bookbuilding (Benveniste and Spindt 1989). Using a sample of 955 IPOs during 1993 and 1994, Chen and Cotter (2002) find a significant negative relation between the waiting period (a proxy for information) and underpricing.

By contrast, we find a significant positive relation between the waiting period and underpricing. In our view, since the waiting period reflects the views of multiple constituents associated with an IPO (and not just institutional demand), the greater ex ante uncertainty associated with a longer waiting period should result in greater underpricing. Note further that the sample used in Chen and Cotter (2002) is substantially different from that in our study. For one, the sample period in that paper is two years as compared to 26 years in ours. Furthermore, the sample exclusions in their study are different from ours, which are consistent with those in most IPO studies. The authors report mean and median underpricing of 9.115\% and 4.2\% respectively while the corresponding values in our sample are $24.63 \%$ and $10.94 \%$ (even if we exclude the bubble period, the respective values are $14.59 \%$ and $8.33 \%$ ). Further, our empirical methodology accounts for the endogeneity of the waiting period.

Section 2 examines the determinants of the waiting period while Section 4 discusses the empirical findings. The data used in the study is presented in Section 3. The impact of the waiting period on underpricing and post-IPO uncertainty is explored in Sections 5 and 6 respectively while Sections 7 and 8 deal with stock performance and operating performance respectively. Section 9 concludes. 


\section{Determinants of the waiting period}

When a U.S. firm wants to go public for the first time, it initially files with the SEC an S-1 or equivalent registration statement giving details about the firm and its intended offering. The expected offer price and number of primary/secondary shares to be offered are often disclosed in an amended filing later. Subsequently, the firm goes on the roadshow marketing the issue to prospective institutional investors. After the roadshow, the firm and underwriter make a decision whether to go ahead with the offering or not and, if yes, the final number of shares and the offer price are stated. With this background, we next examine the various factors that we expect to influence the waiting period for firms that go public.

\subsection{Ex ante uncertainty}

\subsubsection{Underwriter reputation and compensation}

Almost all IPOs in the U.S. use underwriters to market themselves to institutional investors via a roadshow (called “bookbuilding”). Many studies (Carter and Manaster 1990; Megginson and Weiss 1991; Beatty and Welch 1996; Habib and Ljungqvist 2001) have argued that high underwriter reputation helps to reduce the information asymmetry between the firm and prospective investors.

"One problem with using market share or a proxy like tombstone rankings to measure underwriter reputation or quality is that the specific tasks for which the underwriter is rewarded are undefined or, at best, ambiguous. What do higher quality underwriters promise and presumably deliver?” (Krigman, Shaw, and Womack 2001, p. 247).

The question posed above is a valid one. We argue that a short waiting period is one such promise and delivery by high reputation underwriters for several reasons. First, highly reputed 
underwriters have significant reputational capital. As a result, they are able to convince institutional investors to make purchase decisions more easily than low reputation underwriters, which could result in a shorter waiting period. High reputation underwriters also tend to be the larger banks and thus have more resources at their disposal to "efficiently" conduct the IPO. Since market conditions can worsen overnight, and given their desire to protect their reputation, high reputation underwriters would prefer not to be exposed to the greater market volatility associated with longer registration periods. If underwriters with higher reputations are better able to reduce the uncertainty of aggregate market demand through their marketing efforts, we should observe a negative relation, on average, between the registration period and underwriter reputation.

Despite all arguments in its favor, going public quicker would not be beneficial to the issuer if it came at the expense of price discovery and resulted in a relatively low offer price. In this regard, Colaco and Hegde (2013) find that high reputation underwriters extract better values for their clients while taking them public quicker. Specifically, they find that the daily value of information (DVI), measured as the industry-adjusted percent change in price (and proceeds) between that stated initially and the offer, and scaled by the waiting period, is significantly higher for high reputation underwriters as compared to low reputation underwriters. In other words, high reputation underwriters are able to extract better values for their clients while taking them public quicker.

It is also likely that new issues characterized by shorter waiting periods are able to negotiate lower gross spreads (presumably due to lower asymmetric information problems). Here, Corwin and Schultz (2005, p. 476) find that gross spreads are positively correlated with the aftermarket standard deviation of returns from days 21 through 125 following the IPO. However, 
Chen and Ritter (2000) and more recent updates on Professor Jay Ritter's website point out that underwriter compensation in the form of the gross spread tends to be mostly $7 \%$ for moderatesized IPOs (i.e., \$20 million <= IPO proceeds < \$80 million), which suggests that the waiting period may be relatively stable for moderate-sized IPOs.

\subsubsection{Venture capital backing}

Like high reputation underwriters, venture capitalists (VCs) add credibility to a firm going public since they typically accept only one out of every 100 proposals for funding that they receive. Many studies (e.g., Megginson and Weiss (1991)) have found that the certification of firm quality provided by venture capitalists helps to reduce the level of IPO underpricing. The benefits may accrue even earlier and hence we expect VC-backed firms to have a shorter waiting period. It is possible, however, that venture capitalists provide additional funding to a firm while it is in registration. This would be more likely to occur for firms that are taking a long time to go public. If this is the case, then the capital provided by the venture capitalist may, temporarily at least, reduce the urgency for external funds and thus allow the firm the luxury to delay the final offer, which would suggest a positive relation between VC-backing and the waiting period.

\subsubsection{Auditor reputation}

As per SEC requirements, certification of the financial statements by external auditors is required before the firm goes public. Michaely and Shaw (1995) argue that prestigious auditors help to reduce the uncertainty about future cash flows and thus underpricing. The authors further argue that, like investment banks, auditors have reputations to protect and thus they have the incentive to screen prospective IPOs and audit only the less risky ones, more so because they could be 
sued by shareholders if the IPO performs poorly. Michaely and Shaw (1995) find that prestigious auditors are more likely to have larger clients with lower debt ratios. Not surprisingly, the authors find that underpricing is significantly lower for IPOs that use highly reputed auditors and the cross-sectional variance in returns is approximately one-half that of less reputable auditors.

Auditor reputation may play a part in determining the waiting period since high reputation auditors may make the SEC's scrutiny "easier" as well as reassure investors about the quality of internal controls and accounting reports, thus leading to a shorter waiting period. However, we are mindful of the fact that high reputation auditors (e.g., Arthur Andersen) have been associated with accounting scandals (e.g., Enron Corporation in 2001) which may not necessarily give high reputation auditors an advantage over their low reputation counterparts.

\subsubsection{Institutional demand and changes in material information}

The success or failure of any IPO ultimately rests with how institutional investors perceive the firm and its offering. Strong demand in the primary market reflects a high expected rate of growth in revenues and earnings of a new firm, which is arguably the greatest source of uncertainty. Further, it indicates that the quality of disclosures and investor protection is superior as judged by large institutional investors. These factors should enable the issuer and investors to negotiate the final offer price expeditiously. On the other hand, if a going public firm is marked by weak growth prospects, poor investor protection mechanisms, lack of transparency and more ex ante information asymmetry, we would expect a weak or negative investor response, prompting the issuer to lower the offer price or delay the offering. Therefore, the strength of institutional demand discovered during bookbuilding serves as a comprehensive gauge of the salient growth, agency and information profile of the new firm and a fundamental determinant of 
the waiting period. How institutional investors perceive the IPO can be directly observed by comparing the expected offer price with the actual offer price, referred to as the price update.

New issues spend, on average, about three to four months to comply with the registration requirements (Bouis 2009; PricewaterhouseCoopers 2011). The registration watchdog, the SEC, requires firms to file amendments when there is a change in material information (e.g., expected offer price) that prospective investors should be aware of (Bradley and Jordan 2002; Loughran and Ritter 2002), which could lead to further delays. Boone, Floros, and Johnson (2016) note that many IPO firms redact proprietary information from their SEC registration filings, leading to greater initial underpricing, but superior financial performance post-IPO. Moreover, large absolute changes in price may indicate high valuation uncertainty thus resulting in longer waiting periods.

\subsubsection{Other}

When a firm raises a large amount in the IPO, it is likely to take more time to sell the issue. However, a large IPO may be indicative of lower information asymmetry and thus should sell relatively quickly. Bouis (2009) finds that that firms that raised higher IPO proceeds from May 1996 to December 2007 took longer to go public on the New York Stock Exchange (NYSE), but there was no significant effect on NASDAQ. Similarly, older firms at the IPO have less ex ante uncertainty (Barry, Muscarella, and Vetsuypens 1991; Ritter 1991), which should result in a shorter waiting period. Older firms, however, are more complex in their structure and would presumably require more due diligence on the part of the SEC, especially following the Enron Corporation bankruptcy in 2001 which was related to its creation of certain special purpose 
entities. Insofar as we are unable to effectively control for SEC-related delays, we may find a positive relation rather than a negative one.

The IPO proceeds may also include insider sales, a greater percentage of which would send a negative signal to investors about the future prospects of the firm, which could result in delays in going public. Further, Ang and Brau (2003) point out that insiders use concealing and confounding strategies to disguise the true extent of insider selling because of the negative information conveyed. As a result, secondary shares offered may be a better representative measure of insider selling than secondary shares filed if investors anticipate that the latter is downward biased, on average. Finally, the volatility in stock returns within an industry could be viewed as another measure of ex ante uncertainty since a given firm's stock volatility is observable only after the firm goes public (we examine the latter in Section 6).

Ex ante uncertainty proxies (defined in the Appendix):- Underwriter rank, Gross spread, Venture capital, Auditor reputation, Price update, Extreme price update, Amendments, Amount offered, Age, Insider selling, Std. Dev of industry returns (90 days before filing).

\subsection{Legislation/Regulatory issues}

Enacted in 2002 in response to a surge in corporate accounting scandals (including those at Enron Corporation and WorldCom Inc.), the Sarbanes-Oxley Act (SOX) sought to restore confidence in public financial reporting, which lead to an increase in the number of regulatory and disclosure issues to address with an IPO. Compliance with SOX requirements has become a very challenging process, and the costs of going public and being public and have gone up. ${ }^{2}$ We expect the heightened regulatory scrutiny of the filed initial registration documents to increase the number of amendments. 
Furthermore, in April 2012, President Obama of the United States passed the JOBS Act in order to make it easier and quicker for new firms to go public. The JOBS Act eases disclosure requirements for "emerging growth companies". While we are not able to directly examine the impact of the JOBS Act on the waiting period given that our sample period ends in 2011, we can test if smaller firms (in terms of capitalization and sales) are taking longer to go public postSOX. If this is the case, the JOBS Act may help counter some of the harsher provisions of SOX that are hindering small firms in their quest for capital.

In addition to legislation, stock exchanges have listing requirements that must be met and some are stricter than others (e.g., NYSE). Greater scrutiny by some exchanges could lead to a longer waiting period. In his analysis, Bouis (2009) examines the probability of going public on NYSE, AMEX, and NASDAQ and finds that stock market conditions based on NASDAQ have the strongest influence on the waiting period.

Legislation/Regulatory issues proxies (defined in the Appendix):- SOX, Small capitalization, NYSE, NASDAQ.

\subsection{Competition}

Having disclosed sensitive information about their business plans to the public in the first S-1 filing, firms face increasing threats to their innovative products and services from copycats the longer they remain on the registration shelf. More seriously, pioneering firms in an industry face the possibility that other firms in the same industry may beat them in their desire to obtain equity financing. Since the firm receives no money until it actually goes public, we would expect pioneers to go public relatively quickly, especially if there are other firms in the industry simultaneously in registration. While we expect pioneering firms in an industry to receive strong 
investor interest, it is possible that the high level of idiosyncratic valuation uncertainty associated with these offerings might lengthen the waiting period (Busaba 2006). Further, the presence (or absence, because of withdrawal/postponement) of other IPOs could influence the waiting period. Competition proxies (defined in the Appendix):- Pioneer, Contemporaneous, Withdrawn/Postponed.

\subsection{Efficiency}

Benveniste, Busaba, and Wilhelm (2002) and Benveniste et al. (2003) argue that underwriters bundle IPOs (i.e., take multiple firms public at the same time) in order to spread the costs of information production among firms that go public in the absence of which no firm would want to take the lead in going public only to have other firms' free ride on that information. Boeh and Dunbar (2016) report that the IPO bookrunner's pipeline significantly affects pricing decisions, consistent with market power and agency theories which argue that underwriters use a young or growing pipeline to push for higher underpricing.

Benveniste et al. (2003) and Colaco et al. (2009) find that bundling is greater for high reputation underwriters. The latter argue that this association occurs because underwriters with high reputation have significant reputational capital at stake, so "indirect" learning from contemporaneous IPOs is important given that "direct” learning is unavailable at the time of the initial filing since bookbuilding has not yet formally begun. Despite the greater learning from the bundling of IPOs by high reputation underwriters, we expect the additional efforts involved in taking public several firms at the same time to increase the length of the waiting period of a given firm. 
The bundling argument suggests that high reputation underwriters are involved in taking multiple firms public at the same time. But, even high reputation underwriters have resource constraints. Corwin and Schultz (2005) discuss the role of underwriting syndicates since book managers (i.e., lead underwriters) don't have the resources to take firms public by themselves. They argue that lead underwriters would prefer not to hire more co-managers to take a firm public since the latter are more likely to become lead underwriters in subsequent IPOs. Thus, lead underwriters fear competition. Nevertheless, the risk of taking on an IPO by oneself is fairly substantial for an underwriter. Hence, hiring co-managers is fairly common. We expect an inverse relation between the number of underwriters and the waiting period since each underwriter would be expected to have its own institutional clientele and thus contribute to the more efficient marketing of the IPO.

Efficiency proxies (defined in the Appendix):- Bundle, Lead/co-lead/co-managers.

\subsection{Industry/Market}

Bouis (2009) examines the impact of market conditions on the length of time a firm takes to go public. He finds that firms go public quicker when market valuations are high, and when market returns and market volatility are low. While broad market conditions are important, firms typically compete within an industry for the limited supply of capital from venture capitalists or institutional investors. For example, technology firms face significant competitive threats to their businesses and going public as soon as possible would be in their best interest. Technology firms are also more likely to list on NASDAQ and thus influence the time spent in registration both directly and indirectly (i.e., via the exchange on which it is listed). Hence, it is important to account for industry factors along with broad market factors when examining the waiting period. 
Ibbotson and Jaffe (1975) find that the IPO market is characterized by hot and cold periods. This is evidenced by a spate of IPOs in the late 1990s, referred to as the internet bubble period, which ultimately crashed in 2000 (Ljungqvist and Wilhelm 2003; Lowry, Officer, and Schwert 2010). While the IPO can be withdrawn if market conditions take a turn for the worse during registration, less than $10 \%$ of withdrawn issuers successfully go public a second time (Dunbar and Foerster 2008). Therefore, firms are under pressure to get it right (and quickly) the first time around. The financial crisis of 2008 and 2009 was a difficult period in which to obtain financing and it is likely that firms took longer to go public as a result. ${ }^{3}$

Industry/Market proxies (defined in the Appendix):- Technology, Industry return (90 days before filing), Hot IPO market, Bubble, Crisis.

\section{Data}

The data used in this study is drawn from completed and withdrawn IPOs obtained from the Securities Data Corporation (SDC) New Issues database from 1986 to 2011. As with many previous studies of IPOs, unit offers, closed end funds, American Depository Receipts (ADRs), spinoffs, reverse leveraged buyouts (LBOs), financial firms (SIC code 6xxx), and firms with offer price less than $\$ 5$ are excluded. ${ }^{4}$ We further exclude firms that do not have Center for Research in Security Prices (CRSP) shares codes 10 or 11 and are not listed on Compustat. ${ }^{5}$ After excluding missing observations, we are left with a final sample of 4763 completed IPOs. All dollar amounts are adjusted for inflation using the U.S. GDP Implicit Price Deflator $(2010=100.00)$. All variables used in this study are defined in the Appendix.

Table 1 shows the summary statistics, by calendar year, of our primary variable of interest, the waiting period, which is measured as the number of calendar days between the filing date and 
the issue date. While the average waiting period was less than 100 days every year prior to 2000, it has exceeded that value every year since 2000. Figure 1 displays the generally increasing trend in the median waiting period over our study period, along with the number of new issues.

[Table 1 about here]

The summary statistics of the full sample are shown in Table 2. The average number of days taken to go public is 89 (median 67 days), with a standard deviation of 72 days which reflects substantial variability in the registration period. As a result of the winsorization, the maximum waiting period equals 464 calendar days (i.e., one and a quarter years). The mean and median underpricing computed relative to the $21^{\text {st }}$ trading day after the IPO are $25 \%$ and $11 \%$ respectively. The corresponding values are slightly lower when the first trading day is used instead. The mean and median underwriter ranks are 7.34 and 8 respectively, with higher ranks representing higher reputation of lead underwriters. The average number of lead, co-lead and comanagers participating in the IPO is 2.77 and the median gross spread is $7 \%$. There are nearly three firms, on average, in the underwriter's bundle. ${ }^{6} 47 \%$ of firms are backed by VCs. $91 \%$ of firms use reputed external auditors to audit their financial statements before going public.

[Table 2 about here]

Average assets and capitalization are \$111 million and \$154 million respectively. The amount offered is $\$ 65$ million and insider selling is $4 \%$, on average. ${ }^{7}$ The median firm is eight years old at the time of the IPO. The average price update equals $1.58 \%$ with a median of zero and, relatedly, $17 \%$ of firms file extreme price changes between the initial expected and final offer prices. $39 \%$ of firms are classified as technology and $16 \%$ as pioneers. $16 \%$ of sample firms went public after the passing of SOX and the median number of amendments filed is two. Only $13 \%$ of firms list on NYSE as compared to a whopping 74\% that list on NASDAQ. The median 
numbers of contemporaneous and withdrawn/postponed IPOs are 2 and 1 respectively. $70 \%$ of sample firms went public during a hot IPO market. $14 \%$ of sample firms went public during the bubble period while, not surprisingly, only $1 \%$ of firms did the same during the financial crisis.

\section{Empirical findings of the length of the waiting period}

Since our dependent variable, Waiting period, is a count data variable, and to allow for overdispersion (i.e., conditional variance being significantly higher than the conditional mean), we

use the negative binomial regression model. ${ }^{8}$ Table 3 shows the regression results, with the standard errors of all models adjusted for clustering within Fama and French (1997) industry. Given the relatively high correlation between the number of amendments and SOX (rho=0.46), we initially introduce the two variables separately (Columns 1 and 2). Apart from correlation, causality is another potential problem in that the number of amendments is very likely influenced by the presence (or absence) of SOX. If this is the case, it should not be surprising to find that SOX becomes insignificant when both variables are included in the same regression (Columns 36).

[Table 3 about here]

We also include gross spread in Columns 5 and 6 and capitalization in Columns 4-6. Note that the sample size in Column 6 is restricted to firms with IPO proceeds between $\$ 20$ million and $\$ 80$ million and reduces by 55\% to 2136 firms. Given this, our discussion below is mainly focused on Columns 1-5. We discuss below the average marginal effects of our key variables based on Column 4 except for gross spread which is based on Column 5. However, only regression coefficients are reported in Table 3. 
As regards our ex ante uncertainty proxies, higher reputation underwriters help to reduce the waiting period which is not surprising given that they are able to convince institutional investors to purchase shares in the IPO more easily (than low reputation underwriters) and thus close the IPO more quickly. Increasing underwriter rank by one unit results in a reduction in the waiting period of 6.68 days, which is fairly significant given that market conditions can worsen overnight which may force the firm to withdraw/postpone the IPO. As regards the other key parties involved in an IPO, high reputation auditors drastically reduce the waiting period while VCs appear to have no significant influence. Hiring a high reputation auditor reduces the waiting period by almost eight days.

Firms also appear to go public quicker when the price update is greater. A significantly large price update (in absolute value) as captured by the indicator variable, Extreme price change, reflects greater ex ante uncertainty. We find that the waiting period is significantly longer for these firms, possibly due to greater SEC scrutiny. Firms in this category take eight days longer to go public. The estimate on $\operatorname{Ln}(1+$ Amendments $)$ indicates that a one unit increase in this variable increases the waiting period by almost 34 days. Consistent with the idea that it takes longer to go public in volatile market conditions, the relation between pre-IPO Std. Dev. of industry return and waiting period is positive and significant. Older firms take longer to go public, not surprising given that they are likely to be more complex in their structures than newer firms and thus attract greater SEC scrutiny. There is some evidence that the size of the offer positively influences the waiting period and no evidence that insider selling does the same.

Do new firms shorten the waiting period by raising underwriter compensation? To examine this question, we include gross spread, measured as the percentage of IPO proceeds paid to underwriters. The full sample regression results in Column 5 show that the coefficient estimate 
on gross spread is positive, significant at $1 \%$, suggesting that new issues characterized by shorter waiting periods are able to negotiate lower spreads (presumably due to lower asymmetric information problems). An increase in the gross spread of one unit results in the waiting period increasing by almost four days.

Further, Chen and Ritter (2000) and more recent updates on Professor Ritter's website point out that gross spread tends to be mostly $7 \%$ for moderate-sized IPOs (i.e., $\$ 20$ million <= IPO proceeds $<\$ 80$ million). The gross spread is exactly $7 \%$ for more than three-quarters of IPOs in our sample. So, we rerun the waiting period regression for moderate-sized IPOs, which includes roughly $45 \%$ of the original sample. As expected, gross spread is no longer significant (see Column 6), indicating that waiting period is relatively stable for moderate-sized IPOs. ${ }^{9}$

Focusing next on legislation and regulatory issues, the coefficient on SOX is positive and significant in Column 1 confirming that the greater regulatory scrutiny imposed by SOX on public firms has increased the waiting period. However, the variable is insignificant in Column 3 when the number of amendments is also included which suggests that the number of amendments most likely reflects the impact of SOX. To explore the impact of SOX on small firms, we interact SOX with Small capitalization in Columns 4 and 5. The positive coefficient (significant at the $5 \%$ level) indicates that small firms are spending 13 days longer in registration after the passage of SOX. This finding appears to support the need for improving regulations affecting the access to public capital markets, the basic rationale behind the JOBS Act passed in 2012 in the U.S. which exempts emerging growth companies from a variety of accounting and disclosure rules. ${ }^{10}$ The stock exchange on which the IPO is listed appears to have no significant influence. 
As regards competition, pioneering firms go public quicker which is understandable given that delays may result in competitors beating them to market, especially given that the initial filing would contain significant details about the product or service. A pioneer goes public quicker by more than five days. As shown by the number of contemporaneous IPOs, new firms go public quicker when there are other new issues in that industry over the six-week surrounding period. There is weak evidence that the number of withdrawn/postponed IPOs is positively correlated with the waiting period.

Furthermore, there is evidence that hiring more lead/co-lead/co-managers helps to reduce the waiting period as each underwriter is expected to have its own institutional clientele, thus making the bookbuilding period more efficient. Interestingly, the greater the natural logarithm (log) of number of firms in the lead underwriter's bundle, the longer the waiting period, on average. Thus, the bundling of IPOs by underwriters comes at a price in terms of longer days spent in registration.

Similar to Bouis (2009), we find that the average waiting period is shorter when the equal weighted buy-and-hold industry return 90 trading days before the IPO filing date is higher. Technology firms tend to go public quicker, not surprising since competition in the field is very high and new technologies developed by a competitor may result in a shift in funding. Consistent with our expectations, the average waiting period is shorter during hot IPO market periods and the bubble in particular, but longer during the financial crisis. During a hot IPO market, firms go public ten days quicker while during the bubble period, the waiting period was five days shorter. On the other hand, firms took 41 days longer to go public during the financial crisis.

\section{Waiting period and underpricing}


We have shown that the waiting period is influenced by proxies for ex ante uncertainty, legislation/regulation, competition, efficiency, and industry/market conditions. If the waiting period adequately reflects ex ante uncertainty, we should expect it to be positively correlated with underpricing. Specifically, a short waiting period reflects higher underwriter and auditor reputation, lower underwriter compensation in the form of the gross spread, greater price update reflecting strong investor demand, and less uncertainty as captured in lower extreme price updates, fewer amendments, and lower standard deviation of industry returns, all of which should help to reduce the underpricing discount demanded by investors. On the other hand, long registration periods reflect just the opposite which should increase the level of underpricing.

During the internet bubble of the late 1990s, firms increasingly took the opportunity to go public given the favorable market conditions prevalent at the time. Presumably, it was not very difficult to get institutional investors on board especially if the firm was a dot-com. Not surprisingly, we found in Table 3 that the waiting period was shorter during the bubble period. Several IPO studies have found that underpricing was significantly higher during the bubble period and we are interested in examining if delays in going public during the bubble period had an impact on the level of the underpricing.

Further, Benveniste and Spindt (1989) argue that institutional investors are rewarded with underpricing for revealing strong demand during bookbuilding, in the absence of which there would be no incentive for them to do so. Hanley (1993) empirically finds that this is the case and documents a significant positive relation between the price update and underpricing. However, the impact of the price update on underpricing is likely to be influenced by the amount of time over which investor demand is revealed. More specifically, the level of underpricing is unlikely to be the same when institutional demand is revealed more quickly than at a more leisurely pace. 
Our control variables include the uncertainty measures used earlier in our waiting period regressions except for $\operatorname{Ln}(1+$ Amendments), Gross spread, and Std. Dev. of industry return (90 days before filing). We do not include the number of amendments because it is a determinant of the waiting period and, therefore, indirectly impacts underpricing. Similarly, we do not include the gross spread as a control variable since we already include underwriter reputation, which is highly negatively correlated with the gross spread. Finally, we include a variable to capture volatility of industry returns between the filing and offer (since it is more appropriate) and, hence, exclude the industry volatility measure stated above.

\subsection{OLS results}

We present the results of the impact of the waiting period on underpricing in Table 4. To minimize the effect of underwriter price stabilization in the aftermarket, we follow Lowry, Officer, and Schwert (2010) and measure the degree of underpricing as the percentage difference between the market price at the close of the $21^{\text {st }}$ day of trading and the final offer price, Underpricing21. We also capture the more traditional measure of underpricing based on the closing price of the first day of trading, Underpricing1. The dependent variables in Panels A and B are Underpricing21 and Underpricing1 respectively. The t-statistics of all models are adjusted for clustering within Fama and French (1997) industry. In both panels, the waiting period is assumed to be exogenous in the first three regression models. To reduce skewness, we take the natural logarithm (log) of the waiting period.

[Table 4 about here]

Focusing on Panel A, the coefficient of Ln(Waiting period) is negative but insignificant (Column 1). We next interact Ln(Waiting period) with Bubble to examine if investors reacted 
differently during the bubble period to the time spent in registration (Column 2). The coefficient estimate on Ln(Waiting Period) is 3.322 and that on the interaction term is -39.35, the latter highly significant. These results suggest that the average underpricing increases by over $3 \%$ for a one unit increase in the (log of) waiting period when firms go public outside the bubble period. In sharp contrast, initial returns drop, on average, by $36 \%$ (i.e., $-39.35 \%+3.322 \%$ ) for a one unit increase in the (log of) waiting period when firms go public during the bubble period.

One possible explanation for this result is that, during bubble periods, investors would be expected to reveal their demand quicker given that the IPO market is hot, thus allowing for a faster issue. It is not unreasonable to assume that the underpricing reward given to investors for revealing their demand would be reduced if this was not the case. To put it differently, if a firm took a long time to go public during the bubble, it would be associated with a lower level of underpricing.

In Column 3, we interact Ln(Waiting period) with Price update to see if the time period over which institutional demand is revealed impacts the relation between price update and level of underpricing. This interaction term, like the one above, is highly negatively significant and we offer a somewhat similar explanation. When demand from investors is strong (as reflected in a greater price update following bookbuilding), firms should expect to go public quicker. However, when investor demand is strong but revealed over a longer time period, the level of underpricing compensation to investors will be reduced. We conclude that institutional investors should reveal their interest in the IPO in a timely manner when demand for the IPO is strong such as during a bubble period or be prepared to forego a portion of the underpricing.

To illustrate the economic significance of the impact of the waiting period on underpricing, recall (from Table 2) that the mean and standard deviation of initial returns are $24.63 \%$ and 
53.27\% respectively. The mean and standard deviation of $\operatorname{Ln}$ (Waiting period) are 4.30 and 0.56 respectively (not reported). The coefficient estimate of 3.322 on Ln(Waiting period) indicates that, outside of the bubble period, if the (log of) waiting period increases by one standard deviation from its mean (holding all other covariates at their respective means), the average underpricing increases by $1.86 \%(=(3.322 * 0.56) \%)$, which is roughly $3.5 \%$ the standard deviation of underpricing. Thus, the economic impact of the waiting period on underpricing appears to be quite significant. Our results are qualitatively similar when the dependent variable is Underpricing1 (Panel B, Columns 1-3).

\subsection{IV-2SLS results}

The waiting period is at least partly endogenous for the simple reason that the firm and its underwriters decide when to begin and end the registration process, subject to SEC approval. This could make our previous estimates biased. Therefore, we model underpricing in the instrumental variable framework using two-stage least squares with Ln(Waiting period) as the endogenous variable. In the first stage, we regress $L n$ (Waiting period) on the independent variables from the second stage regression and any additional independent variables from Table 3 Column 5 (i.e., the instruments).

The results can be seen in Columns 4-6 of Table 4 Panels A and B (for the respective underpricing measure). Focusing on Panel A, Ln(Waiting period) is highly positively significant (at the $1 \%$ level) indicating that longer registration periods involve greater uncertainty, thus underpricing is higher (Column 4). In Column 5, in addition to the endogeneity of Ln(Waiting period), we assume endogeneity of the interaction term of Ln(Waiting period) with Bubble. As 
additional instruments in our first stage regression, we include the interaction terms of Bubble with each variable in Table 3 Column 5 (except with itself).

The same applies to Column 6 where, in addition to the endogeneity of Ln(Waiting period), we assume endogeneity of the interaction term of Ln(Waiting period) with Price update. Once again we include additional instruments in our first stage, this time interacting Price update with each variable in Table 3 Column 5 (except with itself). Consistent with our findings in the OLS regressions, the interaction terms in Columns 5 and 6 are highly negatively significant. Our findings suggest that, after accounting for the endogeneity of the waiting period, institutional investors are compensated with greater underpricing when registration periods are longer (reflecting greater uncertainty). However, the level of compensation is reduced if investors do not reveal their interest quickly when demand is strong. These results are generally confirmed in Panel B using our alternative underpricing measure although the interaction of Ln(Waiting period) with Price update (Column 6) is not significant.

The results of the control variables are mostly consistent with those in previous IPO studies. In particular, the positive relation between underwriter rank and underpricing is consistent with the argument in Liu and Ritter (2011, p. 587) that issuers are focused on nonprice-related underwriter services such as quality of service, distribution, and investment community influence. As a result, highly reputed underwriters are compensated for providing these services which explains the positive relation between underwriter reputation and underpricing. This is in sharp contrast to the negative relation expected under the underwriter certification argument where high reputation underwriters are assumed to reduce the information asymmetry between the firm and prospective investors, thus resulting in lower underpricing. 
Lee and Wahal (2004) argue that grandstanding by VCs most likely explains the positive relation between VC-backed IPOs and underpricing. When endogeneity is controlled for, VCbacked IPOs are significantly more underpriced than non-VC backed IPOs. The future flow of capital into VC funds is positively related to underpricing and, as a result, the authors argue that the ability to raise future capital is a benefit that offsets the cost of underpricing. Also, Liu and Ritter (2011) argue that VCs are willing to use underpricing to pay the lead underwriter for allstar analyst coverage that is bundled with IPO underwriting. They show that VC-backed IPOs are more underpriced when the lead underwriter provides all-star analyst coverage. Finally, Aggarwal, Krigman, and Womack (2002) argue that underpricing attracts analyst coverage postIPO which results in a higher stock price at lockup expiration, the earliest that VCs can cash out.

In conclusion, our analysis suggests that the number of days spent in registration, which is known to investors at the time of setting the final offer price, has the advantage of being a useful ex ante proxy for the uncertainty of IPO valuations.

\section{Waiting period and post-IPO uncertainty}

In Section 4, we found that the waiting period reflects ex ante uncertainty and, not surprisingly, we found the waiting period to be positively correlated with underpricing in the previous section. Taking this argument forward, we propose that new issues that spend fewer days in the registration process should reflect less uncertainty in the aftermarket. We use three measures to capture post-IPO uncertainty: - return volatility, standard deviation of long-term growth forecasts, and standard deviation of EPS forecasts.

\subsection{Return volatility}


As in Loughran and McDonald (2013, p. 319), we use the actual post-IPO daily stock return volatility as an ex post benchmark of uncertainty. Return volatility is measured as the root-meansquare error based on the market model using the value-weighted index and daily stock returns from CRSP for the following periods (based on trading days) relative to the IPO date:- +21 to $+79 ;+21$ to $+142 ;+21$ to $+205 ;+21$ to +268 . Similar to the intuition behind our underpricing measure, Underpricing21, the first twenty trading days are ignored here because underwriter price support for the IPO may distort stock returns.

Table 5 Panel A shows that the average post-IPO return volatility is 0.04 for Short waiting period IPOs and 0.045 for Long waiting period IPOs for the +21 to +79 period. The t-test based on the difference in means is highly significant as is the Wilcoxon rank sum test of difference in distributions. ${ }^{11}$ Thus, fast moving IPOs have less stock return volatility. We observe similar patterns for the other three periods. Not surprisingly, volatility increases as the length of the period increases.

[Table 5 about here]

In a multivariate context (Panel B), Ln(Waiting period) has a positive and highly significant impact on post-IPO stock return volatility for each of the four periods. Our control variables in these regressions are influenced by those in Loughran and McDonald (2013, Table 8). ${ }^{12}$ In this regard, price update, underwriter reputation, VC-backing, and industry performance are positively correlated with stock return volatility while firm size, insider selling, and EPS have the opposite effect.

\subsection{Standard deviation of long-term growth forecasts}


We define this variable, based on Moeller, Schlingemann, and Stulz (2007), as the most recently available standard deviation of operating earnings long-term growth forecasts from I/B/E/S for 90-, 180-, 270-, and 360-calendar days following the IPO. For the period 90-days post-IPO, the average standard deviation is 5.57 for Short waiting period IPOs and a significantly higher (at the 10\% level) 6.43 for Long waiting period IPOs (Table 5 Panel A). The rank sum test is highly significant (at the 1\% level). As regards 180-days post-IPO, the average standard deviation is 5.61 for Short waiting period IPOs and 6.66 for Long waiting period IPOs. The t-test is highly significant (at the 1\% level) as is the rank sum test. We observe a similar pattern for 270- and 360-days post-IPO.

The multivariate regression results confirm the significant positive relationship between the waiting period and the volatility of long-term growth forecasts (Panel C). Our control variables are the same as those in the stock return volatility regressions and the results are somewhat consistent with those in Panel B.

\subsection{Standard deviation of EPS forecasts}

When the earnings of a firm are difficult to estimate, analyst estimates are likely to diverge (D'Mello and Ferris 2000). Further, Kovner (2012) posits that more opaque firms should have higher standard deviation of earnings estimates. Based on Loh (2010), this variable is captured as the most recently available standard deviation of forecasts of annual one-year-ahead EPS for 90-, 180-, 270-, and 360-calendar days following the IPO, scaled by the absolute value of the mean EPS forecast on the same date. The EPS forecast data is from I/B/E/S Summary History file.

As shown in Table 5 Panel A, the mean standard deviation for EPS forecasts for 90-days post-IPO is 0.10 for Short waiting period IPOs and 0.16 for Long waiting period IPOs. For 180- 
days post-IPO, the same is 0.10 and 0.13 respectively. The t-test and rank sum test are both highly significant for these periods. For the 270- and 360-days post-IPO periods, however, the ttest is not significant but the rank sum test remains highly significant (at the $1 \%$ level). Thus, overall, the standard deviation of EPS forecasts appears to be positively associated with the waiting period.

Our multivariate regression results show that the waiting period positively influences the volatility of EPS forecasts for the 90-day post-IPO period and the significance level is very high (Panel D). However, the coefficient is not significant for the other three periods. Our control variables are the same as those in Panels B and C and provide evidence that price update (-), firm size (+), insider selling (-), EPS (-), and industry return (-) have some influence over the volatility of EPS forecasts. Standard errors of all regression models in Table 5 are adjusted for clustering within Fama and French (1997) industry.

\section{Waiting period and stock performance}

\subsection{Buy-and-hold abnormal returns}

We first examine whether the waiting period has predictive power for the buy-and-hold abnormal returns (BHARs) for 1-, 2-, and 3-years following the IPO, using the methodology in Ritter (2015). Specifically, we match each IPO firm in our sample with a firm in the same equity book-to-market decile that has the closest market capitalization using the merged CRSPCompustat database. ${ }^{13}$ The matched firm must have been listed on CRSP for at least five years and must not have conducted a seasoned equity offering during the previous five years. We calculate the BHAR for firm $i$ over horizon $T$ (where $T=1-$, 2-, or 3-years following the IPO) as 


$$
B H A R_{i, T}=\prod_{t=1}^{\min (T, \text { delist })}\left(1+R_{i, t}\right)-\prod_{t=1}^{\min (T, \text { delist })}\left(1+R_{\text {match }, t}\right)
$$

where $R_{i, t}$ is the daily net return for IPO firm $i$ at time $t$, and $R_{\text {match }, t}$ is the daily net return for the matched firm at time $t$. The returns are measured from the first closing market price to the earlier of the anniversary (1-, 2-, or 3-years, as appropriate) or the delisting date.

Based on this computation, the mean BHAR for short waiting period (tercile 1) firms for 1year after the IPO is $-14.42 \%$ while that for long waiting period (tercile 3 ) firms is $-24.13 \%$ and the difference is highly significant (at the 5\% level) based on a t-test (not reported). For 2-years after the IPO, short waiting period firms have a mean BHAR of $-11.97 \%$ while the corresponding value for long waiting period firms is $-28.01 \%$ (and the difference is highly significant at the 5\% level). Finally, for 3-years after the IPO, the mean BHAR for short (long) waiting period firms is $-10.88 \%(-32.84 \%)$, and the difference between the two groups is once again highly significant at the 5\% level. The Wilcoxon rank sum test of difference in distributions between short and long waiting period firms is also highly significant at the $1 \%$ level for all three time periods. Our results are qualitatively similar if we classify short and long waiting periods based on the median.

We next perform OLS regressions of the BHARs on the waiting period to determine if the time spent in registration can indicate future stock performance. However, BHARs suffer from cross-correlation in calendar time and, if not adjusted, can lead to biased test statistics (Fama 1998; Brav 2000). To counter this, we cluster the standard errors on calendar month (i.e., month and year). When we regress the 1-, 2-, and 3-year BHARs on Ln(Waiting period) (Table 6 Panel A Columns 1-3 respectively), we find that the waiting period is negatively correlated with stock performance for up to three years after the IPO. These results are confirmed for Waiting period 
dummy (Columns 4-6) where the dummy variable equals 1 for long waiting period (tercile 3 ) and 0 for short waiting period (tercile 1 ). Thus, the waiting period has predictive power for future stock performance. ${ }^{14}$

[Table 6 about here]

\subsection{Calendar-time portfolios}

Following Fama (1998), Lyon, Barber, and Tsai (1999), Brav (2000), and Mitchell and Stafford (2000), we use calendar-time portfolio regressions to examine whether new issues marked by shorter waiting periods experience stronger stock market performance over 1-, 2-, and 3-years following the IPO. We form equally-weighted IPO portfolios for short waiting period (tercile 1) and long waiting period (tercile 3) firms. ${ }^{15}$ We regress monthly portfolio returns against the three factors from Fama and French (1993)

$$
R_{p t}-R_{f t}=\alpha+\beta\left(R_{m t}-R_{f t}\right)+s S M B_{t}+h H M L_{t}+e_{t}
$$

and the four factors from Carhart (1997).

$$
R_{p t}-R_{f t}=\alpha+\beta\left(R_{m t}-R_{f t}\right)+s S M B_{t}+h H M L_{t}+m W M L_{t}+e_{t}
$$

In these regressions, $R_{p}$ is the equal-weighted IPO portfolio return, $R_{f}$ is the risk-free rate, $R_{m}$ is the CRSP value-weighted market index return, $S M B$ is the small-firm portfolio return minus big-firm portfolio return, $H M L$ is the high book-to-market portfolio return minus low book-to-market portfolio return, and $W M L$ is the past winner portfolio return minus past loser portfolio return, all measured at time $t$. The abnormal returns (alphas) are captured by the intercepts, and standard errors are adjusted based on White (1980).

In Panel B of Table 6, the mean 1-year post-IPO abnormal return (0.000338) for the short waiting period portfolio is not significantly different from zero (Model 1), but the mean alpha (- 
0.0151) for the long waiting period portfolio is significantly negative (Model 2). The $\mathrm{R}^{2}$ for each regression is in excess of $75 \%$. In Model 3, we regress the difference in monthly returns between the short and long waiting period portfolios on the same independent variables as in Models 1 and 2, thus mimicking a trading strategy of going long in the short waiting period portfolio and short in the portfolio of long waiting period firms. The alpha estimate (0.0154) is positive and significant at 1\%. We find similar results using the Carhart (1997) four-factor model. The alpha estimates of the return differences are once again positive and significant for the 2-year post-IPO period in both sets of models (Panel C). For the 3-year post-IPO period, the alpha estimate on the Fama-French model is significant but that on the Carhart model is not (Panel D). These test results show that the waiting period has reliable predictive power for 1-year, 2-years, and even 3years post-IPO stock performance. ${ }^{16}$

\section{Waiting period and operating performance}

Finally, we examine if IPOs with shorter registration periods are associated with better operating performance in the aftermarket. Following Jain and Kini (1994), we use four measures to capture operating performance: - i) operating return on assets (ROA) is operating income before depreciation divided by total assets, ii) operating cash flow (defined as operating income before depreciation minus capital expenditure) scaled by total assets, iii) operating profit margin is operating income before depreciation divided by net sales, iv) operating cash flow divided by net sales.

Univariate tests in Panel A of Table 7 show that firms with short waiting periods have positive average ROA for the first three years after the IPO (5.27\%, 3.3\%, and 2.22\% respectively). On the other hand, long waiting period firms have near zero or negative mean 
ROA for the corresponding period. The t-tests of difference in means are highly significant at the $1 \%$ level as are the differences in distributions based on the Wilcoxon rank sum tests for all three years. For the other three measures, average operating performance for short waiting period firms is negative but that for long waiting period firms is more negative and the t-test is highly significant. The Wilcoxon test is also highly significant.

[Table 7 about here]

Next, we perform OLS regressions to test whether firms that spend more days in registration perform poorly in the aftermarket. The dependent variable is ROA captured for up to three years after the IPO. Our independent variable of interest is $\operatorname{Ln}$ (Waiting period) and Table 6 from Chemmanur and He (2011) is used as a guide for our control variables. Standard errors of all regression models are adjusted for clustering within Fama and French (1997) industry. Our sample size drops significantly in these regressions since data on research and development expenditure and, to a much lesser extent, capital expenditure is not always available on Compustat.

In Model 1 of Table 7 Panel B, the coefficient estimate on Ln(Waiting period), -0.02 , is significant at $1 \%$, consistent with our prediction. For a one standard deviation (0.55) decrease in the (log of) waiting period from the sample mean, holding all other covariates at their respective means, the average ROA for the first year post-IPO increases by $1.1 \%(=(0.02 * 0.55)$ which equates to $7 \%$ of the standard deviation of ROA (15.31\%, not reported). Thus, the economic impact of the predictive power of the waiting period appears to be quite significant. We obtain similar results for the ROA regressions for years 2 and 3 post-IPO (see Models 2 and 3). ${ }^{17}$ The results of the control variables are consistent with those in Chemmanur and He (2011) ${ }^{18}$ In sum, 
we find strong evidence that new issues with short waiting periods exhibit higher operating performance for up to three years in the aftermarket.

\section{Conclusion}

The amount of time that firms spend from the filing of the preliminary prospectus to the final public offering of shares reflects the summary judgment of multiple monitors of the quality of a new issue, such as underwriters, auditors, institutional investors, listing exchanges, venture capitalists, regulators, etc. Thus, the length of the waiting period provides a comprehensive assessment of new issues' intrinsic quality. We predict that a new issue that goes public quickly reflects less ex ante uncertainty and, thus, should experience lower underpricing and post-IPO uncertainty.

Based on a large sample of 4763 completed IPOs in the United States from 1986-2011, we find that ex ante uncertainty plays a key role in determining the length of the waiting period. Higher underwriter/auditor reputation and greater institutional demand help to reduce the waiting period while greater underwriter compensation, large price updates, older firms, greater number of amendments filed, and higher industry volatility increase the waiting period. Further, we find that a shorter waiting period is, on average, associated with lower underpricing, lower post-IPO return volatility, lower standard deviation of post-IPO EPS and long-term growth forecasts, and higher stock/operating performance. Overall, our results suggest that the length of the waiting period is a critically important gauge of new issue quality and a significant predictor of underpricing and post-IPO uncertainty and performance.

Our analysis indicates that smaller firms are taking longer to go public after the passage of SOX and thus the 2012 JOBS Act designed to make it easier for them to access the public equity 
markets could be useful. Regulatory policies should pay close attention to the cost-benefit trade-

off between the length of the registration period and investor protection.

\section{Notes}

${ }^{1}$ Numbers based on the $5^{\text {th }}$ and $95^{\text {th }}$ percentiles of our dataset.

2 The Act requires the management (CEO and CFO) of a public firm to certify that its financial statements are accurate, comply with the requirements of the exchange acts, and information reported is fairly presented. External auditors are required to annually attest to the effectiveness of the company's internal control over financial reporting, and are prohibited from providing certain non-audit services. A public firm must have an independent audit committee with at least one member qualified as a financial expert, and a majority of members of its board of directors must be from outside the company. For details, see PricewaterhouseCoopers (2011).

${ }^{3}$ Boone, Floros, and Johnson (2016) report that the number of IPOs dropped following the financial crisis (Table 1).

4 These exclusions (with the exception of the \$5 price restriction) apply to our withdrawn/postponed IPO sample as well, which is solely used to determine the number of withdrawn/postponed IPOs, used later in the paper. The withdrawn/postponed IPO sample used also excludes firms with missing SIC codes as we are not able to determine the Fama and French (1997) industry. As such, we do not provide any summary statistics on the withdrawn/postponed IPO sample and all references to the data henceforth pertain to the completed IPO sample only.

${ }^{5}$ Bouis (2009) reports (in Table 1) a minimum registration period length of 20 days and a maximum of 1016 days. We checked the SEC filings (in the Electronic Data Gathering, Analysis, and Retrieval (EDGAR) system from May 1996 onwards) for the correct filing date and/or issue date for IPOs with waiting periods outside this range. SDC was unable to verify the filing date and/or issue date for 76 firms that filed to go public before May and have waiting periods under 20 days. In addition, we are unable to identify waiting periods for two firms that filed for an IPO after May 1996 (one in 1998 and the other in 2005). To be consistent with the sample used in Bouis (2009), these firms are dropped. We also drop firms that are not listed on CRSP within 60 trading days of the issue date.

${ }^{6}$ If there is more than one lead underwriter on a given IPO, the number of firms in the bundle of each lead underwriter is taken and the average computed.

${ }^{7}$ CRSP captures only the class of shares that trades, which is problematic for firms with multiple classes of shares. Thus, the denominator is likely to be downward biased resulting in an upward bias of this variable.

${ }^{8}$ See Cameron and Trivedi (2005)for details.

9 The high negative correlation of -0.68 between underwriter rank and gross spread raises the possibility of multicollinearity issues. However, our results in Columns 5 and 6 are qualitatively similar if we exclude underwriter rank from this regression. We also tried replacing gross spread with underwriting fee, a subcomponent (see Chen and Ritter (2000, Table 5)). We lose 627 and 164 observations respectively as a result when we rerun Columns 5 and 6, and underwriting fee is insignificant in both regressions. The other results are qualitatively similar.

${ }^{10}$ If, instead of capitalization, we use sales constructed in a similar way (i.e., dummy variable that equals one if bottom tercile, and zero otherwise), the interaction term is not significant.

${ }^{11}$ While we do not report rank sums, the actual rank sums are always less (more) than the expected rank sums for Short waiting period (Long waiting period) IPOs for our three measures over all four periods.

12 Our results are qualitatively similar if we use the measures used in Loughran and McDonald (2013):- +5 to +63; +5 to +126 ; +5 to +189 ; +5 to +252 (trading days $1-4$ are ignored since there may be unusual trading activity because of share flipping). Further, our sample size reduces because EPS is available for only 4511 firms. Mean Positive EPS dummy is 0.53 implying that roughly half the sample firms have positive EPS just before the IPO. 
${ }^{13}$ We lose some observations because either the IPO firm or the matched firm has a negative book-to-market equity value. We permit up to five matches for a given IPO firm.

${ }^{14}$ However, these results may be suspect given that Barber and Lyon (1997) report that long-term BHARs can be highly skewed. To reduce skewness, we add the scalar 32 to each return (so as not to lose any observations because of negative returns) and then take the natural logarithm. The results are qualitatively similar.

${ }^{15}$ For 1-year post-IPO performance, our monthly portfolios essentially begin in February 1986 (one month after the beginning of our sample period in January 1986) and end in December 2010 (twelve months after the end of our sample period in December 2009). Similarly, when examining 2-year and 3-year post-IPO performance, our monthly portfolio returns potentially begin in February 1986 in both cases and end in December 2011 and December 2012 respectively. We drop calendar months with less than five stocks in the portfolio so that outliers do not influence our results.

${ }^{16}$ When we use the five-factor asset pricing model by Fama and French (2015) which includes profitability and investment patterns as the additional two factors influencing stock returns, the alpha estimate is positively significant for the 1-year and 2-years post-IPO periods but is insignificant for 3-years post-IPO.

${ }^{17}$ When we examine the three alternative operating performance measures for up to three years after the IPO, we find that $L$ (Waiting period) continues to be highly negatively significant in seven of the nine regressions, the only exceptions being the first year post-IPO for our third and fourth measures (i.e., with sales in the denominator) where Ln(Waiting period) is not significant. Further, our results qualitatively remain the same if we include industry fixed effects as in Chemmanur and He (2011). Finally, our results are not affected by replacing missing observations of research and development expenditure and capital expenditure with zeros (missing values in Compustat presumably imply non-existent or insignificant values).

${ }^{18}$ Based on the available observations in our ROA regression models for the first three years after the IPO:- Mean Capitalization are \$132 million, \$108 million, and \$98 million respectively; Mean R\&D/Assets are 11\%, 14\%, and $16 \%$ respectively; Mean CapEx/PPE are 55\%, 51\%, and 40\% respectively. 


\section{References}

Aggarwal, R. K., L. Krigman, and K. L. Womack. 2002. "Strategic IPO underpricing, information momentum, and lockup expiration selling." Journal of Financial Economics 66 (1): 105-37.

Ang, J. S., and J. C. Brau. 2003. "Concealing and confounding adverse signals: insider wealth-maximizing behavior in the IPO process." Journal of Financial Economics 67 (1): $149-72$.

Barber, B. M., and J. D. Lyon. 1997. "Detecting long-run abnormal stock returns: The empirical power and specification of test statistics." Journal of Financial Economics 43 (3): 341-72.

Barry, C. B., C. J. Muscarella, and M. R. Vetsuypens. 1991. "Underwriter warrants, underwriter compensation, and the costs of going public." Journal of Financial Economics 29 (1): 113-35.

Beatty, R. P., and I. Welch. 1996. "Issuer expenses and legal liability in initial public offerings." Journal of Law and Economics 39 (2): 545-602.

Benninga, S., M. Helmantel, and O. Sarig. 2005. "The timing of initial public offerings." Journal of Financial Economics 75 (1): 115-32.

Benveniste, L. M., W. Y. Busaba, and W. J. Wilhelm. 2002. "Information externalities and the role of underwriters in primary equity markets." Journal of Financial Intermediation 11 (1): 61-86.

Benveniste, L. M., A. Ljungqvist, W. J. Wilhelm, and X. Y. Yu. 2003. "Evidence of information spillovers in the production of investment banking services." Journal of Finance 58 (2): 577-608.

Benveniste, L. M., and P. A. Spindt. 1989. "How investment bankers determine the offer price and allocation of new issues." Journal of Financial Economics 24 (2): 343-61.

Boeh, K. K., and C. Dunbar. 2016. "Underwriter deal pipeline and the pricing of IPOs." Journal of Financial Economics 120 (2): 383-99.

Boone, A. L., I. V. Floros, and S. A. Johnson. 2016. "Redacting proprietary information at the initial public offering." Journal of Financial Economics 120 (1): 102-23.

Bouis, R. 2009. "The short-term timing of initial public offerings." Journal of Corporate Finance 15 (5): 587-601.

Bradley, D. J., and B. D. Jordan. 2002. "Partial adjustment to public information and IPO underpricing." Journal of Financial and Quantitative Analysis 37 (4): 595-616.

Brav, A. 2000. "Inference in Long-Horizon Event Studies: A Bayesian Approach with Application to Initial Public Offerings." Journal of Finance 55 (5): 1979-2016.

Busaba, W. Y. 2006. "Bookbuilding, the option to withdraw, and the timing of IPOs." Journal of Corporate Finance 12 (2): 159-86. 
Cameron, A. C., and P. K. Trivedi. 2005. Microeconometrics: methods and applications. New York: Cambridge University Press.

Carhart, M. M. 1997. "On Persistence in Mutual Fund Performance." Journal of Finance 52 (1): 57-82.

Carter, R. B., and S. Manaster. 1990. "Initial Public Offerings and Underwriter Reputation." Journal of Finance 45 (4): 1045-67.

Chemmanur, T. J., and J. He. 2011. "IPO waves, product market competition, and the going public decision: Theory and evidence." Journal of Financial Economics 101 (2): 382412.

Chen, A., and J. F. Cotter. 2002. "The long-run performance and pre-selling information of initial public offerings." Advances in Investment Analysis and Portfolio Management 9: 203-32.

Chen, H. C., and J. R. Ritter. 2000. "The seven percent solution." Journal of Finance 55 (3): 1105-31.

Colaco, H. M. J., C. Ghosh, J. D. Knopf, and J. L. Teall. 2009. "IPOs, clustering, indirect learning and filing independently." Journal of Banking \& Finance 33 (11): 2070-9.

Colaco, H. M. J., and S. P. Hegde. 2013. "Underwriter Reputation, Bookbuilding and IPO Duration." In Handbook of Research on IPOs, edited by Mario Levis and Silvio Vismara. Cheltenham, UK; Northampton, MA, USA: Edward Elgar publishing.

Corwin, S. A., and P. Schultz. 2005. "The Role of IPO Underwriting Syndicates: Pricing, Information Production, and Underwriter Competition." Journal of Finance 60 (1): 443-86.

D'Mello, R., and S. P. Ferris. 2000. "The information effects of analyst activity at the announcement of new equity issues." Financial Management 29 (1): 78-95.

Draho, J. 2000. "The timing of initial public offerings: A real option approach." Available at SSRN: $\underline{\text { https://ssrn.com/abstract=271351 or http://dx.doi.org/10.2139/ssrn.271351 }}$

Dunbar, C. G., and S. R. Foerster. 2008. "Second time lucky? Withdrawn IPOs that return to the market." Journal of Financial Economics 87 (3): 610-35.

Fama, E. F. 1998. "Market efficiency, long-term returns, and behavioral finance." Journal of Financial Economics 49 (3): 283-306.

Fama, E. F., and K. R. French. 1993. "Common risk factors in the returns on stocks and bonds." Journal of Financial Economics 33 (1): 3-56.

Fama, E. F., and K. R. French. 1997. "Industry costs of equity." Journal of Financial Economics 43 (2): 153-93.

Fama, E. F., and K. R. French. 2015. "A five-factor asset pricing model." Journal of Financial Economics 116 (1): 1-22. 
Field, L. C., and J. M. Karpoff. 2002. "Takeover defenses of IPO firms." Journal of Finance 57 (5): 1857-89.

Habib, M. A., and A. P. Ljungqvist. 2001. "Underpricing and entrepreneurial wealth losses in IPOs: Theory and evidence." Review of Financial Studies 14 (2): 433-58.

Hanley, K. W. 1993. "The underpricing of initial public offerings and the partial adjustment phenomenon." Journal of Financial Economics 34 (2): 231-50.

Ibbotson, R. G., and J. F. Jaffe. 1975. "'Hot Issue" Markets." Journal of Finance 30 (4): 1027-42.

Jain, B. A., and O. Kini. 1994. "The Post-Issue Operating Performance of IPO Firms." Journal of Finance 49 (5): 1699-726.

Kovner, A. 2012. "Do underwriters matter? The impact of the near failure of an equity underwriter." Journal of Financial Intermediation 21 (3): 507-29.

Krigman, L., W. H. Shaw, and K. L. Womack. 2001. "Why do firms switch underwriters?" Journal of Financial Economics 60 (2-3): 245-84.

Lee, P. M., and S. Wahal. 2004. "Grandstanding, certification and the underpricing of venture capital backed IPOs." Journal of Financial Economics 73 (2): 375-407.

Liu, X., and J. R. Ritter. 2011. "Local underwriter oligopolies and IPO underpricing." Journal of Financial Economics 102 (3): 579-601.

Ljungqvist, A., and W. J. Wilhelm. 2003. "IPO pricing in the dot-com bubble." Journal of Finance 58 (2): 723-52.

Loh, R. K. 2010. "Investor Inattention and the Underreaction to Stock Recommendations." Financial Management 39 (3): 1223-52.

Loughran, T., and B. McDonald. 2013. "IPO first-day returns, offer price revisions, volatility, and form S-1 language." Journal of Financial Economics 109 (2): 307-26.

Loughran, T., and J. R. Ritter. 2002. "Why don't issuers get upset about leaving money on the table in IPOs?" Review of Financial Studies 15 (2): 413-43.

Loughran, T., and J. R. Ritter. 2004. "Why has IPO underpricing changed over time?" Financial Management 33 (3): 5-37.

Lowry, M., M. S. Officer, and G. W. Schwert. 2010. "The variability of IPO initial returns." Journal of Finance 65 (2): 425-65.

Lyon, J. D., B. M. Barber, and C. L. Tsai. 1999. "Improved methods for tests of long-run abnormal stock returns." Journal of Finance 54 (1): 165-201.

Megginson, W. L., and K. A. Weiss. 1991. "Venture Capitalist Certification in Initial Public Offerings." Journal of Finance 46 (3): 879-903. 
Michaely, R., and W. H. Shaw. 1995. "Does the Choice of Auditor Convey Quality in an Initial Public Offering?" Financial Management 24 (4): 15-30.

Mitchell, M. L., and E. Stafford. 2000. "Managerial decisions and long-term stock price performance." Journal of Business 73 (3): 287-329.

Moeller, S. B., F. P. Schlingemann, and R. M. Stulz. 2007. "How Do Diversity of Opinion and Information Asymmetry Affect Acquirer Returns?" Review of Financial Studies 20 (6): 2047-78.

Pastor, L., and P. Veronesi. 2005. "Rational IPO Waves." Journal of Finance 60 (4): 171357.

PricewaterhouseCoopers. 2011. "Roadmap for an IPO: A guide to going public." Available at http://www.pwc.com/us/en/deals/publications/assets/roadmap-to-an-ipo.pdf.

Ritter, J. R. 1991. "The Long-run Performance of Initial Public Offerings." Journal of Finance 46 (1): 3-27.

Ritter, J. R. 2015. "Growth Capital-Backed IPOs." Financial Review 50 (4): 481-515.

White, H. 1980. "A Heteroskedasticity-Consistent Covariance Matrix Estimator and a Direct Test for Heteroskedasticity." Econometrica 48 (4): 817-38.

Yung, C., G. Çolak, and W. Wei. 2008. "Cycles in the IPO market." Journal of Financial Economics 89 (1): 192-208. 
Table 1 . Waiting period by year.

\begin{tabular}{rrrrrrrrr}
\hline Year & N & Mean & Std. Dev. & Min & P25 & Median & P75 & Max \\
\hline 1986 & 195 & 42.95 & 12.12 & 20 & 36 & 41 & 48 & 104 \\
1987 & 172 & 46.81 & 29.89 & 20 & 35 & 41 & 50 & 268 \\
1988 & 63 & 54.25 & 41.50 & 20 & 31 & 42 & 55 & 207 \\
1989 & 62 & 57.66 & 56.99 & 28 & 38 & 43.5 & 52 & 464 \\
1990 & 84 & 58.37 & 41.32 & 20 & 41.5 & 47 & 55 & 232 \\
1991 & 212 & 66.09 & 53.29 & 20 & 42 & 48 & 61 & 319 \\
1992 & 294 & 73.04 & 56.49 & 28 & 46 & 55 & 70 & 464 \\
1993 & 370 & 76.03 & 73.15 & 20 & 47 & 54 & 64 & 464 \\
1994 & 311 & 76.39 & 54.33 & 20 & 48 & 62 & 80 & 464 \\
1995 & 375 & 70.94 & 62.27 & 22 & 47 & 56 & 69 & 464 \\
1996 & 548 & 75.61 & 49.95 & 22 & 53 & 63 & 77.5 & 464 \\
1997 & 374 & 92.73 & 61.88 & 23 & 61 & 70.5 & 98 & 464 \\
1998 & 218 & 95.26 & 62.58 & 39 & 63 & 76 & 105 & 464 \\
1999 & 385 & 94.64 & 65.61 & 25 & 65 & 75 & 94 & 464 \\
2000 & 307 & 109.60 & 62.62 & 24 & 75 & 90 & 125 & 464 \\
2001 & 53 & 156.70 & 109.58 & 24 & 82 & 119 & 189 & 464 \\
2002 & 50 & 135.70 & 107.14 & 55 & 74 & 86 & 168 & 464 \\
2003 & 47 & 134.26 & 125.26 & 29 & 69 & 81 & 125 & 464 \\
2004 & 131 & 119.82 & 65.09 & 54 & 83 & 102 & 133 & 464 \\
2005 & 114 & 144.46 & 90.70 & 20 & 83 & 105 & 179 & 464 \\
2006 & 112 & 137.29 & 81.67 & 37 & 91 & 109.5 & 142.5 & 464 \\
2007 & 118 & 136.79 & 83.58 & 38 & 88 & 104 & 162 & 460 \\
2008 & 16 & 175.94 & 78.42 & 91 & 123.5 & 147.5 & 226.5 & 371 \\
2009 & 35 & 242.29 & 176.55 & 30 & 87 & 113 & 464 & 464 \\
2010 & 63 & 137.08 & 77.54 & 49 & 92 & 106 & 153 & 464 \\
2011 & 54 & 171.00 & 109.92 & 68 & 94 & 118 & 186 & 464 \\
\hline Total & 4763 & 88.92 & 71.91 & 20 & 50 & 67 & 96 & 464 \\
\hline & & & & & & & & \\
\hline
\end{tabular}

Notes: The sample includes completed IPOs from 1986-2011 after excluding unit offers, closed end funds, ADRs, spinoffs, reverse LBOs, financial firms (SIC code 6xxx), firms with offer price less than $\$ 5$, and firms that do not have CRSP share codes 10 or 11 . The table shows year-wise statistics of Waiting period (defined in Appendix) based on year in which IPO was completed. 
Table 2. Summary statistics.

\begin{tabular}{|c|c|c|c|c|c|c|c|c|}
\hline & $\mathrm{N}$ & Mean & Std. Dev. & Min & P25 & Median & P75 & Max \\
\hline Waiting period & 4763 & 88.92 & 71.91 & 20 & 50 & 67 & 96 & 464 \\
\hline Underpricing21 & 4763 & 24.63 & 53.27 & -42.61 & -3.75 & 10.94 & 34.72 & 295.83 \\
\hline Underpricing1 & 4763 & 19.81 & 37.92 & -15.1 & 0 & 7.5 & 24.2 & 225.89 \\
\hline Underwriter rank & 4763 & 7.34 & 2.08 & 1 & 7 & 8 & 9 & 9 \\
\hline Lead/co-lead/co-managers & 4763 & 2.77 & 1.65 & 1 & 2 & 2 & 3 & 11 \\
\hline Gross spread & 4763 & 7.18 & 0.94 & 1 & 7 & 7 & 7 & 16 \\
\hline Bundle & 4763 & 2.78 & 3.56 & 0 & 0 & 1.5 & 4 & 17.33 \\
\hline Venture capital & 4763 & 0.47 & 0.5 & 0 & 0 & 0 & 1 & 1 \\
\hline Auditor reputation & 4763 & 0.91 & 0.29 & 0 & 1 & 1 & 1 & 1 \\
\hline Price update & 4763 & 1.58 & 23.69 & -75.57 & -11.11 & 0 & 11.11 & 220 \\
\hline Extreme price update & 4763 & 0.17 & 0.37 & 0 & 0 & 0 & 0 & 1 \\
\hline Amendments & 4763 & 2.69 & 2.17 & 0 & 1 & 2 & 4 & 9 \\
\hline Pioneer & 4763 & 0.16 & 0.37 & 0 & 0 & 0 & 0 & 1 \\
\hline SOX & 4763 & 0.16 & 0.36 & 0 & 0 & 0 & 0 & 1 \\
\hline NYSE & 4763 & 0.13 & 0.33 & 0 & 0 & 0 & 0 & 1 \\
\hline NASDAQ & 4763 & 0.74 & 0.44 & 0 & 0 & 1 & 1 & 1 \\
\hline Assets & 4763 & 111.37 & 316.75 & 0.29 & 6.47 & 17.87 & 58.64 & 2320.99 \\
\hline Capitalization & 4763 & 154.13 & 248.36 & 0 & 26.17 & 64.72 & 169.94 & 1553.48 \\
\hline Age & 4763 & 15.02 & 19.53 & 0 & 4 & 8 & 16 & 96 \\
\hline Amount offered & 4763 & 64.5 & 266.34 & 1.04 & 13.61 & 28.31 & 60.55 & 15774 \\
\hline Insider selling & 4763 & 4.01 & 8.92 & 0 & 0 & 0 & 5.39 & 100 \\
\hline Contemporaneous & 4763 & 4.64 & 7.59 & 0 & 0 & 2 & 5 & 36 \\
\hline Withdrawn/Postponed & 4763 & 1.55 & 2.56 & 0 & 0 & 1 & 2 & 12 \\
\hline Technology & 4763 & 0.39 & 0.49 & 0 & 0 & 0 & 1 & 1 \\
\hline Hot IPO market & 4763 & 0.7 & 0.46 & 0 & 0 & 1 & 1 & 1 \\
\hline Bubble & 4763 & 0.14 & 0.34 & 0 & 0 & 0 & 0 & 1 \\
\hline Crisis & 4763 & 0.01 & 0.1 & 0 & 0 & 0 & 0 & 1 \\
\hline
\end{tabular}

Notes: The sample includes completed IPOs from 1986-2011 after excluding unit offers, closed end funds, ADRs, spinoffs, reverse LBOs, financial firms (SIC code 6xxx), firms with offer price less than \$5, and firms that do not have CRSP share codes 10 or 11 . All variables are defined in Appendix. 
Table 3. Determinants of waiting period.

\begin{tabular}{|c|c|c|c|c|c|c|}
\hline & (1) & $(2)$ & (3) & (4) & $(5)$ & (6) \\
\hline \multicolumn{7}{|l|}{ Ex ante uncertainty } \\
\hline Underwriter rank & $\begin{array}{c}-0.111^{* * *} \\
(-22.69)\end{array}$ & $\begin{array}{c}-0.0791 * * * \\
(-13.77)\end{array}$ & $\begin{array}{c}-0.0776 * * * \\
(-12.80)\end{array}$ & $\begin{array}{c}-0.0755^{* * *} \\
(-11.02)\end{array}$ & $\begin{array}{c}-0.0694^{* * *} \\
(-9.631)\end{array}$ & $\begin{array}{c}-0.0872 * * * \\
(-6.461)\end{array}$ \\
\hline Gross spread & & & & & $\begin{array}{c}0.0436 * * * \\
(4.373)\end{array}$ & $\begin{array}{l}0.0566 \\
(0.904)\end{array}$ \\
\hline Venture capital & $\begin{array}{l}-0.0258 \\
(-1.021)\end{array}$ & $\begin{array}{l}-0.0224 \\
(-0.895)\end{array}$ & $\begin{array}{l}-0.0238 \\
(-0.929)\end{array}$ & $\begin{array}{l}-0.0207 \\
(-0.841)\end{array}$ & $\begin{array}{l}-0.0160 \\
(-0.650)\end{array}$ & $\begin{array}{c}0.00331 \\
(0.116)\end{array}$ \\
\hline Auditor reputation & $\begin{array}{c}-0.128 * * * \\
(-4.046)\end{array}$ & $\begin{array}{c}-0.0921 * * * \\
(-3.258)\end{array}$ & $\begin{array}{c}-0.0886 * * * \\
(-3.141)\end{array}$ & $\begin{array}{c}-0.0876 * * * \\
(-3.088)\end{array}$ & $\begin{array}{c}-0.0795^{* * *} \\
(-2.813)\end{array}$ & $\begin{array}{l}-0.00514 \\
(-0.115)\end{array}$ \\
\hline Price update & $\begin{array}{c}-0.00325 * * * \\
(-9.091)\end{array}$ & $\begin{array}{c}-0.00245^{* * *} \\
(-8.465)\end{array}$ & $\begin{array}{c}-0.00240 * * * \\
(-8.724)\end{array}$ & $\begin{array}{c}-0.00244 * * * \\
(-9.167)\end{array}$ & $\begin{array}{c}-0.00272 * * * \\
(-9.779)\end{array}$ & $\begin{array}{c}-0.00275^{* * *} \\
(-4.733)\end{array}$ \\
\hline Extreme price update & $\begin{array}{c}0.132 * * * \\
(3.728)\end{array}$ & $\begin{array}{c}0.0894 * * \\
(2.429)\end{array}$ & $\begin{array}{c}0.0890 * * \\
(2.395)\end{array}$ & $\begin{array}{c}0.0909 * * \\
(2.441)\end{array}$ & $\begin{array}{c}0.0945 * * \\
(2.573)\end{array}$ & $\begin{array}{l}0.0807 \\
(1.360)\end{array}$ \\
\hline Ln(Amount offered) & $\begin{array}{c}0.0607^{* * *} \\
(5.115)\end{array}$ & $\begin{array}{c}-0.00378 \\
(-0.369)\end{array}$ & $\begin{array}{l}-0.00732 \\
(-0.708)\end{array}$ & $\begin{array}{c}-0.00395 \\
(-0.354)\end{array}$ & $\begin{array}{l}0.0186 \\
(1.492)\end{array}$ & $\begin{array}{l}0.0310 \\
(1.015)\end{array}$ \\
\hline Ln(1+Age) & $\begin{array}{l}0.0180 \\
(1.534)\end{array}$ & $\begin{array}{c}0.0229 * * \\
(2.077)\end{array}$ & $\begin{array}{c}0.0228 * * \\
(2.062)\end{array}$ & $\begin{array}{l}0.0217^{*} \\
(1.956)\end{array}$ & $\begin{array}{c}0.0240 * * \\
(2.158)\end{array}$ & $\begin{array}{c}0.0406 * * * \\
(2.638)\end{array}$ \\
\hline Insider selling & $\begin{array}{c}-0.00124 \\
(-0.886)\end{array}$ & $\begin{array}{l}-1.57 e-05 \\
(-0.0130)\end{array}$ & $\begin{array}{l}-5.53 e-05 \\
(-0.0461)\end{array}$ & $\begin{array}{l}-3.32 e-05 \\
(-0.0278)\end{array}$ & $\begin{array}{c}0.000146 \\
(0.124)\end{array}$ & $\begin{array}{c}-0.000232 \\
(-0.125)\end{array}$ \\
\hline Std. Dev. of industry return (90 days before filing) & $\begin{array}{c}11.06 * * * \\
(3.405)\end{array}$ & $\begin{array}{l}5.856^{*} \\
(1.698)\end{array}$ & $\begin{array}{l}5.927^{*} \\
(1.716)\end{array}$ & $\begin{array}{l}5.895^{*} \\
(1.709)\end{array}$ & $\begin{array}{l}5.597^{*} \\
(1.646)\end{array}$ & $\begin{array}{c}11.51^{* * * *} \\
(3.978)\end{array}$ \\
\hline Ln(1+Amendments) & & $\begin{array}{c}0.384 * * * \\
(11.58)\end{array}$ & $\begin{array}{c}0.378 * * * \\
(12.49)\end{array}$ & $\begin{array}{c}0.380 * * * \\
(12.15)\end{array}$ & $\begin{array}{c}0.373 * * * \\
(11.91)\end{array}$ & $\begin{array}{c}0.315^{* * * *} \\
(6.878)\end{array}$ \\
\hline \multicolumn{7}{|l|}{ Legislation/Regulatory issues } \\
\hline SOX & $\begin{array}{c}0.227 * * * \\
(4.509)\end{array}$ & & $\begin{array}{l}0.0489 \\
(1.221)\end{array}$ & $\begin{array}{l}0.0388 \\
(0.964)\end{array}$ & $\begin{array}{l}0.0294 \\
(0.741)\end{array}$ & $\begin{array}{c}0.111 \\
(1.624)\end{array}$ \\
\hline Small capitalization & & & & $\begin{array}{l}0.0269 \\
(1.040)\end{array}$ & $\begin{array}{l}0.0265 \\
(1.030)\end{array}$ & $\begin{array}{c}0.109 * * * \\
(3.041)\end{array}$ \\
\hline Small capitalization x SOX & & & & $\begin{array}{c}0.144 * * \\
(2.092)\end{array}$ & $\begin{array}{c}0.165^{* *} \\
(2.348)\end{array}$ & $\begin{array}{c}0.00137 \\
(0.00913)\end{array}$ \\
\hline NYSE & $\begin{array}{l}-0.0481 \\
(-1.103)\end{array}$ & $\begin{array}{l}-0.0176 \\
(-0.400)\end{array}$ & $\begin{array}{l}-0.0151 \\
(-0.340)\end{array}$ & $\begin{array}{l}-0.0120 \\
(-0.270)\end{array}$ & $\begin{array}{c}0.00468 \\
(0.103)\end{array}$ & $\begin{array}{l}0.0658 \\
(1.014)\end{array}$ \\
\hline NASDAQ & $\begin{array}{l}-0.0215 \\
(-0.720)\end{array}$ & $\begin{array}{l}-0.0449 \\
(-1.418)\end{array}$ & $\begin{array}{l}-0.0454 \\
(-1.427)\end{array}$ & $\begin{array}{l}-0.0415 \\
(-1.292)\end{array}$ & $\begin{array}{l}-0.0202 \\
(-0.638)\end{array}$ & $\begin{array}{l}0.0466 \\
(0.788)\end{array}$ \\
\hline \multicolumn{7}{|l|}{ Competition } \\
\hline Pioneer & $\begin{array}{c}-0.0631^{* *} \\
(-1.962)\end{array}$ & $\begin{array}{c}-0.0635^{*} \\
(-1.957)\end{array}$ & $\begin{array}{c}-0.0638^{*} \\
(-1.942)\end{array}$ & $\begin{array}{c}-0.0627 * \\
(-1.946)\end{array}$ & $\begin{array}{c}-0.0631^{*} \\
(-1.954)\end{array}$ & $\begin{array}{l}-0.0255 \\
(-0.603)\end{array}$ \\
\hline
\end{tabular}


Ln(1+Contemporaneous)

Ln(1+Withdrawn/Postponed)

\section{Efficiency}

Ln(1+Bundle)

Ln(Lead/co-lead/co-managers)

\section{Industry/Market}

Technology

Industry return (90 days before filing)

Hot IPO market

Bubble

Crisis

Constant

Observations

Log-likelihood

Prob > chi2

Notes: The san

mple includes completed IPOs from 1986-2011 after excluding unit offers, closed end funds, ADRs, spinoffs, reverse LBOs, financial firms (SIC code

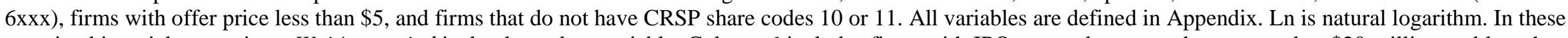

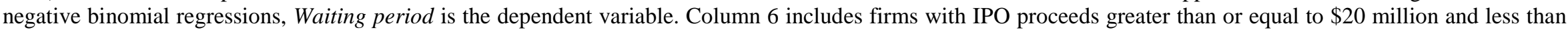

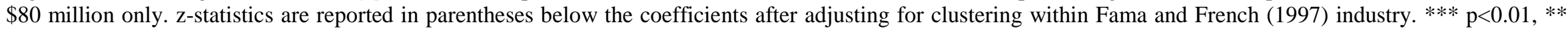
$\mathrm{p}<0.05, * \mathrm{p}<0.1$

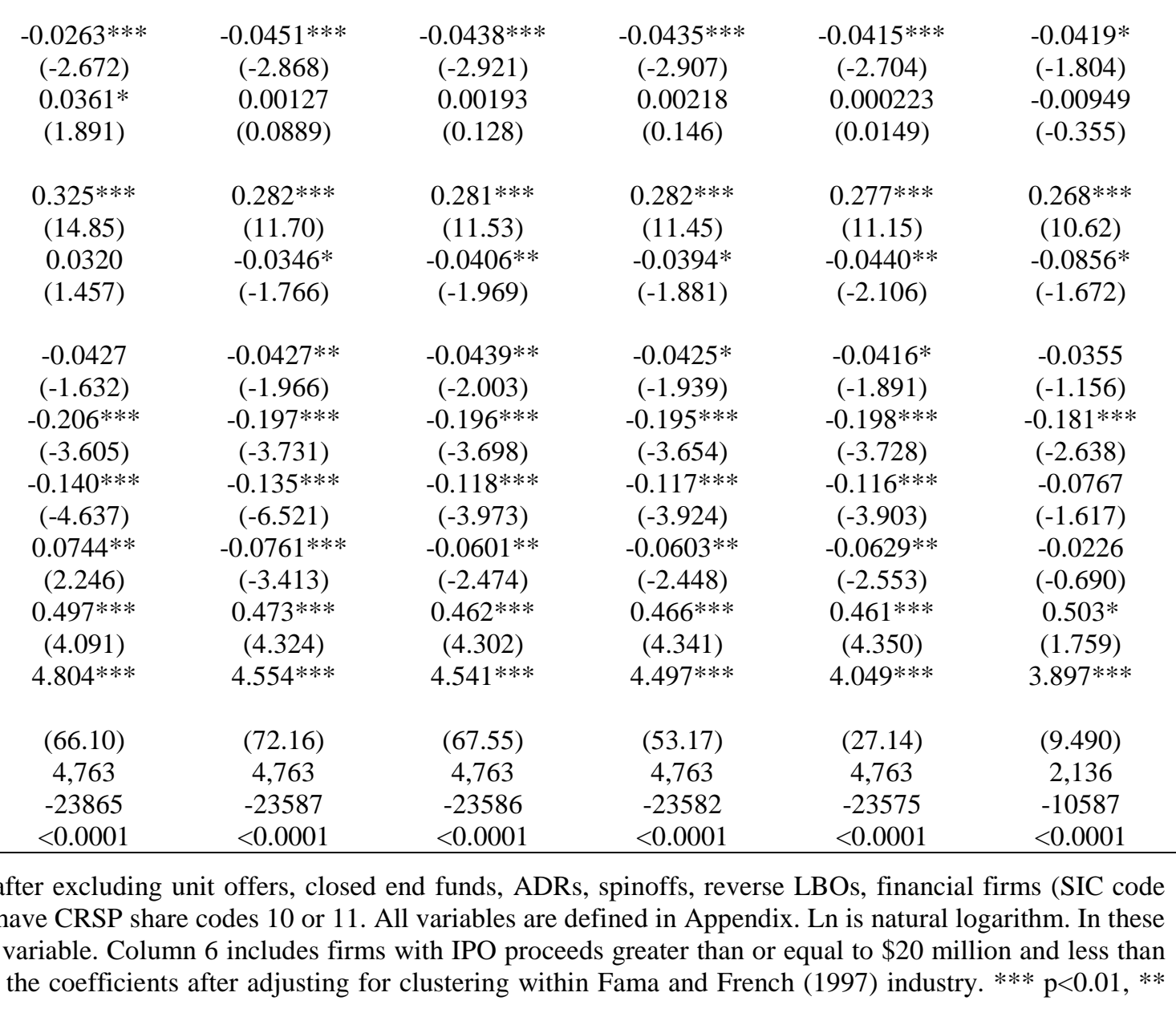


Table 4. Impact of waiting period on underpricing.

Panel A: Underpricing based on $21^{\text {st }}$ trading day

\begin{tabular}{|c|c|c|c|c|c|c|}
\hline & $(1)$ & $(2)$ & $(3)$ & $(4)$ & $(5)$ & $(6)$ \\
\hline \multirow[t]{2}{*}{ Ln(Waiting period) } & -0.186 & $3.322 *$ & -0.341 & $12.40^{* * *}$ & $12.73^{* * *}$ & $11.22^{* * *}$ \\
\hline & $(-0.111)$ & $(1.742)$ & $(-0.229)$ & (5.108) & $(5.891)$ & (5.294) \\
\hline \multirow[t]{2}{*}{ Underwriter rank } & $1.271^{* *}$ & $1.468^{* *}$ & $1.289 * *$ & $1.961^{* * *}$ & $1.986^{* * *}$ & $1.932 * * *$ \\
\hline & $(2.477)$ & $(2.631)$ & $(2.484)$ & (3.986) & $(3.702)$ & (3.685) \\
\hline \multirow[t]{2}{*}{ Venture capital } & $2.024 *$ & 1.855 & 1.878 & $1.988^{*}$ & 1.764 & $1.797^{*}$ \\
\hline & $(1.802)$ & $(1.542)$ & $(1.670)$ & $(1.940)$ & (1.514) & $(1.740)$ \\
\hline \multirow[t]{2}{*}{ Price update } & $0.748^{* * *}$ & $0.745^{* * *}$ & $1.687^{* * *}$ & $0.811^{* * *}$ & $0.784 * * *$ & $2.053^{* * *}$ \\
\hline & (15.89) & (17.08) & (6.110) & $(17.14)$ & (19.83) & (5.755) \\
\hline \multirow[t]{2}{*}{ Extreme price update } & $16.55^{* * *}$ & $15.44^{* * *}$ & $15.56^{* * *}$ & $14.67 * * *$ & $13.79 * * *$ & $13.49 * * *$ \\
\hline & (12.04) & (12.63) & (11.24) & $(9.495)$ & $(10.51)$ & (10.10) \\
\hline \multirow[t]{2}{*}{ Ln(Assets) } & 0.0183 & 0.119 & 0.140 & -0.00410 & 0.146 & 0.159 \\
\hline & $(0.0210)$ & $(0.132)$ & $(0.158)$ & $(-0.00474)$ & $(0.159)$ & $(0.181)$ \\
\hline \multirow[t]{2}{*}{ Ln(Amount offered) } & -1.839 & $-3.096 * * *$ & $-2.054^{*}$ & $-3.588 * * *$ & $-4.713^{* * *}$ & $-3.739 * * *$ \\
\hline & $(-1.628)$ & $(-2.816)$ & $(-1.753)$ & $(-3.116)$ & $(-4.623)$ & $(-3.257)$ \\
\hline \multirow[t]{2}{*}{ Ln(1+Age) } & $-1.936^{* *}$ & $-1.724 *$ & $-1.994 * *$ & $-1.758^{*}$ & -1.527 & $-1.849 * *$ \\
\hline & $(-2.107)$ & $(-1.799)$ & $(-2.230)$ & $(-1.891)$ & $(-1.588)$ & $(-2.046)$ \\
\hline \multirow[t]{2}{*}{ Auditor reputation } & 1.045 & 1.073 & 0.976 & $2.680 *$ & 2.123 & 2.464 \\
\hline & $(0.713)$ & $(0.805)$ & $(0.633)$ & (1.813) & (1.628) & $(1.542)$ \\
\hline \multirow[t]{2}{*}{ Insider selling } & -0.0170 & 0.0131 & -0.0184 & 0.00539 & 0.0394 & 0.00181 \\
\hline & $(-0.382)$ & $(0.327)$ & $(-0.411)$ & $(0.128)$ & $(0.980)$ & $(0.0430)$ \\
\hline \multirow[t]{2}{*}{ Ln(1+Contemporaneous) } & 1.588 & 1.360 & 1.502 & 1.056 & 0.930 & 0.983 \\
\hline & $(1.460)$ & (1.192) & (1.373) & $(0.924)$ & $(0.778)$ & $(0.877)$ \\
\hline \multirow[t]{2}{*}{ NYSE } & 5.134 & $6.197^{*}$ & 5.286 & $5.298^{*}$ & $6.730^{* *}$ & $5.488^{*}$ \\
\hline & $(1.574)$ & $(1.844)$ & $(1.614)$ & (1.657) & $(2.067)$ & (1.735) \\
\hline \multirow[t]{2}{*}{ NASDAQ } & $5.773^{* * *}$ & $5.920 * * *$ & $5.686 * * *$ & $5.756^{* * *}$ & $5.969 * * *$ & $5.642^{* * *}$ \\
\hline & (3.294) & (3.347) & (3.253) & $(3.417)$ & (3.471) & (3.304) \\
\hline \multirow[t]{2}{*}{ Technology } & $6.905^{* *}$ & $6.829 *$ & $6.794 *$ & $7.200^{* *}$ & $6.987^{* *}$ & $7.030^{* *}$ \\
\hline & $(2.027)$ & $(2.004)$ & $(1.980)$ & $(2.126)$ & $(2.061)$ & $(2.047)$ \\
\hline Industry return (filing to offer) & $-15.06^{*}$ & -11.17 & $-14.59 *$ & $-31.07 * * *$ & $-19.77^{* * *}$ & $-29.22 * * *$ \\
\hline
\end{tabular}




\begin{tabular}{|c|c|c|c|c|c|c|}
\hline & $(-1.719)$ & $(-1.286)$ & $(-1.709)$ & $(-4.450)$ & $(-2.855)$ & $(-3.973)$ \\
\hline Hot IPO market & 0.919 & 1.661 & 1.058 & 3.955 & 3.888 & 3.906 \\
\hline \multirow[t]{2}{*}{ Bubble } & $51.98 * * *$ & $228.3 * * *$ & $52.45^{* * *}$ & $53.73^{* * *}$ & $300.5^{* * *}$ & $54.22 * * *$ \\
\hline & $(8.522)$ & $(7.532)$ & $(8.651)$ & (8.341) & $(4.489)$ & (8.553) \\
\hline Crisis & 1.626 & -0.821 & 1.701 & -1.307 & -3.670 & -0.982 \\
\hline \multirow[t]{2}{*}{ Ln(Waiting period) x Bubble } & & $-39.35^{* * *}$ & & & $-55.20 * * *$ & \\
\hline & & $(-6.054)$ & & & $(-3.755)$ & \\
\hline \multirow[t]{2}{*}{ Ln(Waiting period) x Price update } & & & $-0.213^{* * *}$ & & & $-0.282^{* * *}$ \\
\hline & & & $(-3.291)$ & & & $(-3.400)$ \\
\hline \multirow[t]{2}{*}{ Constant } & 5.283 & -9.305 & 5.952 & $-47.12 * * *$ & $-48.47 * * *$ & $-42.21 * * *$ \\
\hline & $(0.801)$ & $(-1.417)$ & $(0.989)$ & $(-3.752)$ & $(-4.737)$ & $(-4.042)$ \\
\hline R-squared & 0.367 & 0.379 & 0.369 & 0.356 & 0.372 & 0.359 \\
\hline
\end{tabular}


Panel B: Underpricing based on $1^{\text {st }}$ trading day

\begin{tabular}{|c|c|c|c|c|c|c|}
\hline & $(1)$ & $(2)$ & (3) & $(4)$ & (5) & $(6)$ \\
\hline \multirow[t]{2}{*}{ Ln(Waiting period) } & -0.251 & $1.927 * *$ & -0.359 & $9.141^{* * *}$ & $10.45^{* * *}$ & $8.671^{* * *}$ \\
\hline & $(-0.357)$ & $(2.268)$ & $(-0.621)$ & $(5.105)$ & $(8.342)$ & $(6.603)$ \\
\hline \multirow[t]{2}{*}{ Underwriter rank } & 0.347 & 0.469 & 0.360 & $0.863 * * *$ & $0.940 * * *$ & $0.848 * * *$ \\
\hline & (1.268) & $(1.590)$ & (1.296) & (3.296) & (3.271) & (3.139) \\
\hline \multirow[t]{2}{*}{ Venture capital } & 1.257 & 1.153 & 1.156 & 1.230 & 1.050 & 1.172 \\
\hline & $(1.503)$ & $(1.372)$ & $(1.411)$ & $(1.549)$ & $(1.298)$ & $(1.540)$ \\
\hline \multirow[t]{2}{*}{ Price update } & $0.765^{* * *}$ & $0.764 * * *$ & $1.417^{* * *}$ & $0.812^{* * *}$ & $0.796 * * *$ & $1.195^{* * *}$ \\
\hline & $(17.17)$ & $(17.86)$ & $(7.246)$ & $(18.68)$ & $(20.61)$ & $(3.758)$ \\
\hline \multirow[t]{2}{*}{ Extreme price update } & $19.98 * * *$ & $19.29 * * *$ & $19.29 * * *$ & $18.58 * * *$ & $17.72^{* * *}$ & $18.23 * * *$ \\
\hline & (10.65) & (11.25) & (10.05) & $(9.002)$ & $(9.900)$ & $(8.819)$ \\
\hline \multirow[t]{2}{*}{ Ln(Assets) } & -0.163 & -0.0999 & -0.0783 & -0.179 & -0.0628 & -0.129 \\
\hline & $(-0.396)$ & $(-0.222)$ & $(-0.197)$ & $(-0.473)$ & $(-0.135)$ & $(-0.345)$ \\
\hline \multirow[t]{2}{*}{ Ln(Amount offered) } & -0.0466 & -0.827 & -0.196 & $-1.352 * *$ & $-2.388 * * *$ & $-1.384 * *$ \\
\hline & $(-0.0715)$ & $(-1.230)$ & $(-0.291)$ & $(-2.048)$ & $(-3.962)$ & $(-2.170)$ \\
\hline \multirow[t]{2}{*}{ Ln(1+Age) } & $-1.298 * * *$ & $-1.167 * * *$ & $-1.338 * * *$ & $-1.165 * * *$ & $-0.968 * *$ & $-1.195 * * *$ \\
\hline & $(-3.336)$ & $(-2.850)$ & $(-3.543)$ & $(-2.859)$ & $(-2.191)$ & $(-3.023)$ \\
\hline \multirow[t]{2}{*}{ Auditor reputation } & $-1.859 * *$ & $-1.842^{* *}$ & $-1.906^{* *}$ & -0.638 & -0.942 & -0.719 \\
\hline & $(-2.106)$ & $(-2.192)$ & $(-2.090)$ & $(-0.699)$ & $(-1.112)$ & $(-0.780)$ \\
\hline \multirow[t]{2}{*}{ Insider selling } & $-0.0922 * *$ & $-0.0735 * *$ & $-0.0931 * *$ & $-0.0754 * *$ & $-0.0467^{*}$ & $-0.0767 * *$ \\
\hline & $(-2.623)$ & $(-2.624)$ & $(-2.588)$ & $(-2.378)$ & $(-1.949)$ & $(-2.413)$ \\
\hline \multirow[t]{2}{*}{ Ln(1+Contemporaneous) } & 0.450 & 0.308 & 0.390 & 0.0530 & -0.0912 & 0.0349 \\
\hline & $(0.821)$ & $(0.532)$ & $(0.715)$ & $(0.0877)$ & $(-0.143)$ & $(0.0595)$ \\
\hline \multirow[t]{2}{*}{ NYSE } & 0.0146 & 0.675 & 0.121 & 0.137 & 1.282 & 0.194 \\
\hline & $(0.00700)$ & $(0.320)$ & $(0.0580)$ & $(0.0658)$ & $(0.591)$ & $(0.0944)$ \\
\hline \multirow[t]{2}{*}{ NASDAQ } & 1.220 & 1.312 & 1.160 & 1.208 & 1.375 & 1.173 \\
\hline & $(0.888)$ & (0.947) & $(0.848)$ & $(0.892)$ & $(0.990)$ & $(0.863)$ \\
\hline \multirow[t]{2}{*}{ Technology } & $3.945 * *$ & $3.898 * *$ & $3.868 * *$ & $4.166^{* *}$ & $4.022 * *$ & $4.111^{* *}$ \\
\hline & (2.123) & (2.112) & (2.058) & (2.283) & $(2.235)$ & $(2.246)$ \\
\hline \multirow[t]{2}{*}{ Industry return (filing to offer) } & -2.846 & -0.432 & -2.523 & $-14.80 * * *$ & $-7.215^{* *}$ & $-14.09 * * *$ \\
\hline & $(-0.689)$ & $(-0.118)$ & $(-0.644)$ & $(-4.528)$ & $(-2.346)$ & $(-3.816)$ \\
\hline
\end{tabular}


Std. Dev. of industry return (filing to offer)

Hot IPO market

Bubble

Crisis

Ln(Waiting period) $x$ Bubble

Ln(Waiting period) $x$ Price update

Constant

$\begin{array}{ccc}33.09 & 87.41 & 56.94 \\ (0.191) & (0.486) & (0.326) \\ 0.627 & 1.087 & 0.723 \\ (0.674) & (1.417) & (0.762) \\ 32.31^{* * *} & 141.8^{* * *} & 32.63^{* * *} \\ (10.57) & (5.909) & (10.83) \\ -0.800 & -2.320 & -0.748 \\ (-0.418) & (-1.161) & (-0.380) \\ & -24.44^{* * *} & \\ & (-4.552) & \end{array}$

$-0.148 * * *$

$(-3.020)$

$10.97 * * *$

(3.478)

1.913

(0.632)

$11.44^{* * *}$
(3.653)

$-203.8$

$(-1.504)$

2.893**

(2.319)

33.61***

(9.699)

$-2.990$

$(-1.421)$

4,763

$-28.15^{* * *}$

(-3.163)
$-41.95$

$(-0.274)$

$3.094 * * *$

(3.110)

$228.7^{* * *}$

(6.007)

$-5.102 * *$

$(-2.158)$

$-43.62 * * *$

(-5.129)

\section{$-0.0870$}

$(-1.133)$

$-33.60 * * *$

(-5.373)

$-26.18 * * *$

Anderson LM test p-value

Observations

4,763

4,763

0.518

$<0.0001$

$<0.0001$

R-squared

$0.516 \quad 0.526$

$<0.0001$
4,763
0.505

4,763

4,763

Notes: The sample includes completed IPOs from 1986-2011 after excluding unit offers, closed end funds, ADRs, spinoffs, reverse LBOs, financial firms (SIC code $6 \mathrm{xxx}$ ), firms with offer price less than \$5, and firms that do not have CRSP share codes 10 or 11 . All variables are defined in Appendix. Ln is natural logarithm. In Panel A (Panel B), Underpricing21 (Underpricing1) is the dependent variable and estimated using OLS (Columns 1-3) and instrumental variable (IV) two-stage least squares regression (Columns 4-6). In the first stage of the IV regressions in Column 4, regressors include all second stage variables and any additional regressors from Table 3 Column 5. In Column 5 (6) we expand the set of first-stage regressors and also include interactions of Bubble (Price update) with the regressors from Table 3 Column 5. t-statistics (for OLS regressions) and z-statistics (for IV regressions) are reported in parentheses below the coefficients after adjusting for clustering within Fama and French (1997) industry. The table reports the p-value of the Anderson canonical correlations Lagrange multiplier test of underidentification whose null hypothesis is that the model is under-identified. *** $\mathrm{p}<0.01,{ }^{* *} \mathrm{p}<0.05,{ }^{*} \mathrm{p}<0.1$ 
Table 5. Waiting period and post-IPO uncertainty.

Panel A: Univariate tests

\begin{tabular}{|c|c|c|c|c|c|c|c|c|}
\hline & \multicolumn{3}{|c|}{ Short waiting period } & \multicolumn{3}{|c|}{ Long waiting period } & \multirow{2}{*}{$\begin{array}{c}\text { t-test } \\
\text { (p- } \\
\text { value) }\end{array}$} & \multirow{2}{*}{$\begin{array}{c}\text { rank sum test } \\
\text { (p-value) }\end{array}$} \\
\hline & $\mathrm{N}$ & Mean & Median & $\mathrm{N}$ & Mean & Median & & \\
\hline \multicolumn{9}{|l|}{ Post-IPO return volatility } \\
\hline+21 to +79 days post-IPO & 2379 & 0.040 & 0.037 & 2384 & 0.045 & 0.040 & $<0.0001$ & $<0.0001$ \\
\hline +21 to +142 days post-IPO & 2379 & 0.042 & 0.040 & 2384 & 0.047 & 0.042 & $<0.0001$ & $<0.0001$ \\
\hline +21 to +205 days post-IPO & 2379 & 0.043 & 0.040 & 2384 & 0.048 & 0.043 & $<0.0001$ & $<0.0001$ \\
\hline+21 to +268 days post-IPO & 2379 & 0.044 & 0.041 & 2384 & 0.049 & 0.044 & $<0.0001$ & $<0.0001$ \\
\hline \multicolumn{9}{|l|}{ Std. Dev. of long-term growth forecasts } \\
\hline 90 days post-IPO & 396 & 5.570 & 3.540 & 647 & 6.425 & 3.540 & 0.0743 & 0.0074 \\
\hline 180 days post-IPO & 738 & 5.607 & 3.540 & 900 & 6.665 & 3.540 & 0.0037 & 0.0034 \\
\hline 270 days post-IPO & 928 & 5.889 & 3.540 & 1015 & 6.677 & 3.790 & 0.0210 & 0.0246 \\
\hline 360 days post-IPO & 1037 & 5.873 & 3.540 & 1088 & 6.748 & 4.060 & 0.0047 & 0.0116 \\
\hline \multicolumn{9}{|l|}{ Std. Dev. of EPS forecasts } \\
\hline 90 days post-IPO & 1142 & 0.096 & 0.034 & 1590 & 0.156 & 0.060 & $<0.0001$ & $<0.0001$ \\
\hline 180 days post-IPO & 1575 & 0.100 & 0.035 & 1824 & 0.126 & 0.047 & 0.0005 & $<0.0001$ \\
\hline 270 days post-IPO & 1741 & 0.113 & 0.038 & 1862 & 0.121 & 0.046 & 0.3221 & $<0.0001$ \\
\hline 360 days post-IPO & 1796 & 0.135 & 0.043 & 1883 & 0.138 & 0.048 & 0.7640 & 0.0013 \\
\hline
\end{tabular}


Panel B: Impact of waiting period on post-IPO return volatility

\begin{tabular}{lcccc}
\hline & $(1)$ & $(2)$ & $(3)$ & $(4)$ \\
\hline Ln(Waiting period) & $0.00542^{* * *}$ & $0.00498^{* * *}$ & $0.00498^{* * *}$ & $0.00501^{* * *}$ \\
& $(6.615)$ & $(5.843)$ & $(6.294)$ & $(5.788)$ \\
Price update & $0.000159^{* * *}$ & $0.000128^{* * *}$ & $0.000104^{* * *}$ & $9.33 \mathrm{e}-05^{* * *}$ \\
& $(6.061)$ & $(5.982)$ & $(5.593)$ & $(4.965)$ \\
Underwriter rank & $0.00126^{* * *}$ & $0.000842^{* *}$ & 0.000461 & 0.000164 \\
& $(3.209)$ & $(2.114)$ & $(1.260)$ & $(0.470)$ \\
Venture capital & $0.00296^{* * *}$ & $0.00337 * * *$ & $0.00325^{* * *}$ & $0.00287^{* * *}$ \\
& $(4.080)$ & $(4.947)$ & $(5.256)$ & $(4.395)$ \\
Ln(Assets) & $-0.00376^{* * *}$ & $-0.00385^{* * *}$ & $-0.00393^{* * *}$ & $-0.00400^{* * *}$ \\
& $(-7.669)$ & $(-7.750)$ & $(-7.889)$ & $(-7.750)$ \\
Insider selling & $-0.000271^{* * *}$ & $-0.000256^{* * *}$ & $-0.000258^{* * *}$ & $-0.000260^{* * *}$ \\
& $(-5.182)$ & $(-4.011)$ & $(-3.761)$ & $(-3.851)$ \\
Positive EPS dummy & $-0.00697^{* * *}$ & $-0.00734^{* * *}$ & $-0.00756^{* * *}$ & $-0.00832^{* * *}$ \\
& $(-4.054)$ & $(-4.213)$ & $(-4.252)$ & $(-4.736)$ \\
Industry return (90 days before filing) & $0.0146^{* * *}$ & $0.0146^{* * *}$ & $0.0141^{* * *}$ & $0.0128^{* * *}$ \\
& $(8.514)$ & $(7.157)$ & $(6.110)$ & $(4.747)$ \\
Constant & $0.0218^{* * *}$ & $0.0290^{* * *}$ & $0.0333^{* * *}$ & $0.0374 * * *$ \\
& $(7.385)$ & $(9.045)$ & $(11.65)$ & $(11.76)$ \\
Observations & & & & 4,511 \\
R-squared & 4,511 & 4,511 & 4,511 & 0.282 \\
\hline
\end{tabular}

Panel C: Impact of waiting period on post-IPO volatility of long-term growth forecasts

\begin{tabular}{lcccc}
\hline & $(1)$ & $(2)$ & $(3)$ & $(4)$ \\
\hline Ln(Waiting period) & $0.728^{*}$ & $0.770^{* *}$ & $0.661^{* * *}$ & $1.148^{* * *}$ \\
Price update & $(1.724)$ & $(2.630)$ & $(3.028)$ & $(4.357)$ \\
& $0.0400^{* * *}$ & $0.0459^{* * *}$ & $0.0384^{* * *}$ & $0.0299^{* * *}$ \\
Underwriter rank & $(5.077)$ & $(7.312)$ & $(5.789)$ & $(5.436)$ \\
& $0.472^{* *}$ & $0.445^{*}$ & 0.280 & $0.535^{* *}$ \\
Venture capital & $(2.180)$ & $(2.003)$ & $(1.021)$ & $(2.441)$ \\
& $2.501^{* * *}$ & $1.369^{* * *}$ & $1.761^{* * *}$ & $0.650^{* *}$ \\
Ln(Assets) & $(6.800)$ & $(4.125)$ & $(7.615)$ & $(2.034)$ \\
& -0.196 & $-0.365^{* *}$ & $-0.413^{* * *}$ & $-0.628^{* * *}$ \\
Insider selling & $(-1.339)$ & $(-2.580)$ & $(-2.950)$ & $(-4.059)$ \\
& $-0.0238^{*}$ & -0.00720 & $-0.0380^{* * *}$ & $-0.0452^{* * *}$ \\
Positive EPS dummy & $(-2.001)$ & $(-0.272)$ & $(-4.501)$ & $(-4.312)$ \\
Industry return (90 days before filing) & $-1.757 * * *$ & $-2.550^{* * *}$ & $-2.720^{* * *}$ & $-2.878^{* * *}$ \\
& $(-3.075)$ & $(-6.877)$ & $(-8.502)$ & $(-9.317)$ \\
Constant & 0.335 & $2.568^{* * *}$ & $3.353^{* * *}$ & $3.662^{* * *}$
\end{tabular}


$(-0.349)$

Observations

R-squared
(0.273)

982

0.105
1,550

0.120
(1.118)

1,828

0.136
(0.00145)

1,999

0.136

Panel D: Impact of waiting period on post-IPO volatility of EPS forecasts

\begin{tabular}{lcccc}
\hline & $(1)$ & $(2)$ & $(3)$ & $(4)$ \\
\hline Ln(Waiting period) & $0.0303^{* * *}$ & 0.00765 & -0.00930 & -0.0147 \\
& $(3.236)$ & $(0.903)$ & $(-1.485)$ & $(-1.220)$ \\
Price update & -0.000108 & $-7.52 \mathrm{e}-05$ & $-0.000297^{* *}$ & $-0.000338^{* *}$ \\
& $(-0.786)$ & $(-0.405)$ & $(-2.321)$ & $(-2.237)$ \\
Underwriter rank & 0.00166 & -0.00172 & -0.00327 & 0.000391 \\
& $(0.444)$ & $(-0.451)$ & $(-0.766)$ & $(0.0797)$ \\
Venture capital & 0.00587 & 0.0110 & 0.00536 & -0.00556 \\
& $(0.632)$ & $(1.240)$ & $(0.750)$ & $(-0.404)$ \\
Ln(Assets) & $0.0148^{* *}$ & 0.00429 & -0.00419 & -0.00360 \\
& $(2.626)$ & $(0.760)$ & $(-0.916)$ & $(-0.784)$ \\
Insider selling & -0.000435 & -0.000170 & $-0.000631^{* *}$ & $-0.000745^{*}$ \\
& $(-0.750)$ & $-0.292)$ & $(-2.265)$ & $(-1.863)$ \\
Positive EPS dummy & $-0.110^{* * *}$ & $-0.104^{* * *}$ & $-0.0916^{* * *}$ & $-0.0866^{* * *}$ \\
& $(-5.885)$ & $(-6.201)$ & $(-7.100)$ & $(-6.723)$ \\
Industry return (90 days before filing) & -0.00778 & -0.0236 & $-0.0317 *$ & 0.0255 \\
& $(-0.551)$ & $(-1.400)$ & $(-1.892)$ & $(0.793)$ \\
Constant & -0.0112 & $0.135 * *$ & $0.254^{* * *}$ & $0.257^{* * *}$ \\
& $(-0.306)$ & $(2.518)$ & $(5.639)$ & $(3.755)$ \\
Observations & & & & 3,494 \\
R-squared & 2,603 & 3,232 & 3,415 & 0.026 \\
\hline
\end{tabular}

Notes: The sample includes completed IPOs from 1986-2011 after excluding unit offers, closed end funds, ADRs, spinoffs, reverse LBOs, financial firms (SIC code $6 \mathrm{xxx}$ ), firms with offer price less than $\$ 5$, and firms that do not have CRSP share codes 10 or 11. All variables are defined in Appendix. Ln is natural logarithm. In Panel A, Short waiting period refers to firms with Waiting period less than that of the median. Long waiting period refers to firms with Waiting period greater than or equal to that of the median. In the Panel B OLS regressions, Post-IPO return volatility is the dependent variable and is computed over +21 to +79 (trading) days post-IPO in Column $1,+21$ to +142 days post-IPO in Column 2, +21 to +205 days post-IPO in Column 3, and +21 to +268 days post-IPO in Column 4. In the Panel C OLS regressions, Std. Dev. of long-term growth forecasts is the dependent variable and is computed over 90 (calendar) days post-IPO in Column 1, 180 days post-IPO in Column 2, 270 days post-IPO in Column 3, and 360 days post-IPO in Column 4. In the Panel D OLS regressions, Std. Dev. of EPS forecasts is the dependent variable and is computed over 90 (calendar) days post-IPO in Column 1, 180 days post-IPO in Column 2, 270 days post-IPO in Column 3, and 360 days post-IPO in Column 4. In all regressions, t-statistics are reported in parentheses below the coefficients after adjusting for clustering within Fama and French (1997) industry. *** $\mathrm{p}<0.01,{ }^{* *} \mathrm{p}<0.05,{ }^{*} \mathrm{p}<0.1$ 
Table 6. Waiting period and stock performance.

Panel A: Buy-and-hold abnormal returns (BHARs) for 1-, 2-, and 3-years post-IPO

\begin{tabular}{|c|c|c|c|c|c|c|c|c|}
\hline & & & $(1)$ & $(2)$ & (3) & $(4)$ & $(5)$ & $(6)$ \\
\hline \multicolumn{3}{|c|}{ Ln(Waiting period) } & $\begin{array}{c}-0.0495^{*} \\
(-1.648)\end{array}$ & $\begin{array}{c}-0.104 * * \\
(-1.967)\end{array}$ & $\begin{array}{c}-0.167 * * \\
(-2.365)\end{array}$ & & & \\
\hline \multicolumn{3}{|c|}{ Waiting period dummy } & & & & $\begin{array}{c}-0.0972 * * \\
(-2.089)\end{array}$ & $\begin{array}{c}-0.160 * * \\
(-1.975)\end{array}$ & $\begin{array}{c}-0.220 * * \\
(-2.305)\end{array}$ \\
\hline \multicolumn{3}{|l|}{ Constant } & $\begin{array}{l}0.0129 \\
(0.102)\end{array}$ & $\begin{array}{c}0.253 \\
(1.062)\end{array}$ & $\begin{array}{c}0.508 \\
(1.620)\end{array}$ & $\begin{array}{c}-0.144 * * * \\
(-5.648)\end{array}$ & $\begin{array}{c}-0.120 * * \\
(-2.054)\end{array}$ & $\begin{array}{c}-0.109 \\
(-1.616)\end{array}$ \\
\hline \multicolumn{3}{|c|}{$\begin{array}{l}\text { Observations } \\
\text { R-squared }\end{array}$} & $\begin{array}{l}4,593 \\
0.000\end{array}$ & $\begin{array}{l}4,591 \\
0.001\end{array}$ & $\begin{array}{l}4,589 \\
0.001\end{array}$ & $\begin{array}{l}3,106 \\
0.002\end{array}$ & $\begin{array}{l}3,104 \\
0.002\end{array}$ & $\begin{array}{l}3,104 \\
0.002\end{array}$ \\
\hline \multicolumn{9}{|c|}{ Panel B: Calendar-time portfolio returns (1-year post-IPO) } \\
\hline & $\begin{array}{c}\text { (1) } \\
\begin{array}{c}\text { Short waiting } \\
\text { period }\end{array} \\
\end{array}$ & $\begin{array}{c}\text { (2) } \\
\text { Long waiting } \\
\text { period }\end{array}$ & \multicolumn{2}{|c|}{$\begin{array}{l}\text { Short waiting period - Long } \\
\text { waiting period }\end{array}$} & $\begin{array}{c}\text { (4) } \\
\begin{array}{c}\text { Short waiting } \\
\text { period }\end{array} \\
\end{array}$ & $\begin{array}{c}\text { (5) } \\
\text { Long waiting } \\
\text { period }\end{array}$ & \multicolumn{2}{|c|}{$\begin{array}{c}\text { Short waiting period - Long } \\
\text { waiting period }\end{array}$} \\
\hline $\mathrm{R}_{\mathrm{m}}-\mathrm{R}_{\mathrm{f}}$ & $\begin{array}{c}1.214^{* * *} \\
(14.55)\end{array}$ & $\begin{array}{c}1.217^{* * *} \\
(9.965)\end{array}$ & \multicolumn{2}{|c|}{-0.00335} & $\begin{array}{c}1.208^{* * *} \\
(15.84)\end{array}$ & $\begin{array}{c}1.208^{* * *} \\
(11.27)\end{array}$ & \multicolumn{2}{|c|}{$-2.07 e-05$} \\
\hline SMB & $\begin{array}{c}1.005 * * * \\
(5.057)\end{array}$ & $\begin{array}{c}1.079 * * * \\
(6.386)\end{array}$ & \multicolumn{2}{|c|}{-0.0739} & $\begin{array}{c}1.031^{* * * *} \\
(5.836)\end{array}$ & $\begin{array}{c}1.120 * * * \\
(7.667)\end{array}$ & -0.0893 & \\
\hline HML & $\begin{array}{c}-0.625 * * * \\
(-3.943)\end{array}$ & $\begin{array}{l}-0.329 * \\
(-1.839)\end{array}$ & \multicolumn{2}{|c|}{$-0.296 *$} & $\begin{array}{c}-0.662 * * * \\
(-4.352)\end{array}$ & $\begin{array}{c}-0.389 * * \\
(-2.373)\end{array}$ & \multicolumn{2}{|c|}{$-0.273^{*}$} \\
\hline WML & & & & & $\begin{array}{c}-0.161 \\
(-1.455)\end{array}$ & $\begin{array}{c}-0.259 * * * \\
(-2.744)\end{array}$ & \multicolumn{2}{|c|}{0.0973} \\
\hline$\alpha$ & $\begin{array}{c}0.000338 \\
(0.0935)\end{array}$ & $\begin{array}{c}-0.0151 * * * \\
(-3.612)\end{array}$ & \multicolumn{2}{|c|}{$\begin{array}{c}0.0154 * * * \\
(3.969)\end{array}$} & $\begin{array}{c}0.00203 \\
(0.627)\end{array}$ & $\begin{array}{c}-0.0124 * * * \\
(-3.032)\end{array}$ & \multicolumn{2}{|c|}{$\begin{array}{c}0.0144 * * * \\
(3.835)\end{array}$} \\
\hline \multicolumn{9}{|l|}{ Observatio } \\
\hline R-squared & 0.833 & 0.734 & \multicolumn{2}{|c|}{0.035} & 0.838 & 0.747 & \multicolumn{2}{|c|}{0.042} \\
\hline
\end{tabular}


Panel C: Calendar-time portfolio returns (2-years post-IPO)

\begin{tabular}{|c|c|c|c|c|c|c|}
\hline & $\begin{array}{l}\text { (1) } \\
\text { Short waiting } \\
\text { period }\end{array}$ & $\begin{array}{l}\text { (2) } \\
\text { Long waiting } \\
\text { period }\end{array}$ & $\begin{array}{l}\text { (3) } \\
\begin{array}{l}\text { Short waiting period - Long } \\
\text { waiting period }\end{array} \\
\end{array}$ & $\begin{array}{l}\text { (4) } \\
\text { Short waiting } \\
\text { period }\end{array}$ & $\begin{array}{l}\text { (5) } \\
\text { Long waiting } \\
\text { period }\end{array}$ & $\begin{array}{l}\text { (6) } \\
\text { Short waiting period - Long } \\
\text { waiting period }\end{array}$ \\
\hline $\mathrm{R}_{\mathrm{m}}-\mathrm{R}_{\mathrm{f}}$ & $\begin{array}{c}1.144^{* * *} \\
(14.53)\end{array}$ & $\begin{array}{c}1.188^{* * *} \\
(10.84)\end{array}$ & $\begin{array}{l}-0.0439 \\
(-0.441)\end{array}$ & $\begin{array}{c}1.102^{* * *} \\
(15.14)\end{array}$ & $\begin{array}{c}1.147^{* * *} \\
(13.29)\end{array}$ & $\begin{array}{l}-0.0448 \\
(-0.439)\end{array}$ \\
\hline SMB & $\begin{array}{c}1.002^{* * *} \\
(7.136)\end{array}$ & $\begin{array}{c}1.121^{* * *} \\
(7.926)\end{array}$ & $\begin{array}{c}-0.119 \\
(-1.189)\end{array}$ & $\begin{array}{c}1.043^{* * *} \\
(9.063)\end{array}$ & $\begin{array}{c}1.161^{* * *} \\
(10.83)\end{array}$ & $\begin{array}{c}-0.118 \\
(-1.164)\end{array}$ \\
\hline HML & $\begin{array}{c}-0.699 * * * \\
(-4.928)\end{array}$ & $\begin{array}{l}-0.327 * * \\
(-2.274)\end{array}$ & $\begin{array}{l}-0.372 * * \\
(-2.482)\end{array}$ & $\begin{array}{c}-0.780 * * * \\
(-5.691)\end{array}$ & $\begin{array}{c}-0.406^{* * *} \\
(-3.213)\end{array}$ & $\begin{array}{c}-0.374 * * \\
(-2.490)\end{array}$ \\
\hline WML & & & & $\begin{array}{c}-0.380 * * * \\
(-2.626)\end{array}$ & $\begin{array}{c}-0.371 * * * \\
(-3.948)\end{array}$ & $\begin{array}{l}-0.00880 \\
(-0.0965)\end{array}$ \\
\hline$\alpha$ & $\begin{array}{c}0.000732 \\
(0.241)\end{array}$ & $\begin{array}{c}-0.00706^{*} \\
(-1.944)\end{array}$ & $\begin{array}{c}0.00779 * * \\
(2.390)\end{array}$ & $\begin{array}{c}0.00525 \\
(1.478)\end{array}$ & $\begin{array}{c}-0.00265 \\
(-0.749)\end{array}$ & $\begin{array}{c}0.00790 * * \\
(2.307)\end{array}$ \\
\hline $\begin{array}{l}\text { Observat } \\
\text { ns } \\
\text { R- } \\
\text { squared }\end{array}$ & $\begin{array}{r}185 \\
0.847 \\
\end{array}$ & $\begin{array}{r}185 \\
0.774 \\
\end{array}$ & $\begin{array}{r}185 \\
0.066 \\
\end{array}$ & $\begin{array}{r}185 \\
0.878 \\
\end{array}$ & $\begin{array}{r}185 \\
0.804 \\
\end{array}$ & $\begin{array}{r}185 \\
0.066 \\
\end{array}$ \\
\hline anel D & dar-time portfol & eturns (3-years & $\mathrm{PO})$ & & & \\
\hline & $\begin{array}{l}\text { (1) } \\
\text { Short waiting } \\
\text { period }\end{array}$ & $\begin{array}{l}\text { (2) } \\
\text { Long waiting } \\
\text { period }\end{array}$ & $\begin{array}{l}\text { (3) } \\
\text { Short waiting period - Long } \\
\text { waiting period }\end{array}$ & $\begin{array}{l}\text { (4) } \\
\text { Short waiting } \\
\text { period }\end{array}$ & $\begin{array}{l}\text { (5) } \\
\text { Long waiting } \\
\text { period }\end{array}$ & $\begin{array}{l}\text { (6) } \\
\text { Short waiting period - Long } \\
\text { waiting period }\end{array}$ \\
\hline $\mathrm{R}_{\mathrm{m}}-\mathrm{R}_{\mathrm{f}}$ & $\begin{array}{c}1.193^{* * *} \\
(16.73)\end{array}$ & $\begin{array}{c}1.206^{* * *} \\
(12.12)\end{array}$ & $\begin{array}{l}-0.0129 \\
(-0.152)\end{array}$ & $\begin{array}{c}1.134^{* * *} \\
(17.00)\end{array}$ & $\begin{array}{c}1.126^{* * *} \\
(15.47)\end{array}$ & $\begin{array}{c}0.00813 \\
(0.102)\end{array}$ \\
\hline SMB & $\begin{array}{c}0.980 * * * \\
(7.854)\end{array}$ & $\begin{array}{c}1.147 * * * \\
(8.322)\end{array}$ & $\begin{array}{c}-0.167 \\
(-1.643)\end{array}$ & $\begin{array}{c}1.020 * * * \\
(9.433)\end{array}$ & $\begin{array}{c}1.202 * * * \\
(11.57)\end{array}$ & $\begin{array}{l}-0.181 * \\
(-1.848)\end{array}$ \\
\hline HML & $-0.484 * * *$ & $-0.223^{*}$ & $-0.261^{* *}$ & $-0.541^{* * *}$ & $-0.301^{* * *}$ & $-0.241^{* *}$ \\
\hline
\end{tabular}


WML

$$
0.00340
$$

$-0.00130$

0.00469*

0.00254

\section{Observatio}

ns

R-

Notes: The sample includes completed IPOs from 1986-2011 after excluding unit offers, closed end funds, ADRs, spinoffs, reverse LBOs, financial firms (SIC code $6 \mathrm{xxx}$ ), firms with offer price less than $\$ 5$, and firms that do not have CRSP share codes 10 or 11 . Panel A shows OLS regressions where the dependent variable is buy-and-hold abnormal returns (BHARs) for 1-year (Columns 1 and 4), 2-years (Columns 2 and 5), and 3-years (Columns 3 and 6) post-IPO and are computed as follows:

$$
\text { BHAR }_{i, T}=\prod_{t=1}^{\min (T, \text { delist })}\left(1+R_{i, t}\right)-\prod_{t=1}^{\min (T, \text { delist })}\left(1+R_{\text {match }, t}\right)
$$

$R_{i, t}$ is daily net return for IPO firm $i$ at time $t$ and $R_{\text {match, } t}$ is daily net return for the matched firm at time $t$. The returns are measured from the first closing market price to the earlier of the anniversary (1-, 2-, or 3-years, as appropriate) or the delisting date. Waiting period dummy equals one for firms in Waiting period tercile 3 (Long waiting period) and zero for firms in Waiting period tercile 1 (Short waiting period). Standard errors are adjusted for clustering by calendar month (i.e., month and year).

Panels B, C, and D show 1-year, 2-years, and 3-years post-IPO abnormal stock returns respectively for Waiting period tercile 1 (Short waiting period) and Waiting period tercile 3 (Long waiting period). Abnormal returns are measured by alphas in the following Fama and French (1993) three-factor and Carhart (1997) four-factor regressions respectively:

$$
\begin{gathered}
R_{p t}-R_{f t}=\alpha+\beta\left(R_{m t}-R_{f t}\right)+s S M B_{t}+h H M L_{t}+e_{t} \\
R_{p t}-R_{f t}=\alpha+\beta\left(R_{m t}-R_{f t}\right)+s S M B_{t}+h H M L_{t}+m W M L_{t}+e_{t}
\end{gathered}
$$

$R_{p}$ is equal-weighted IPO portfolio return, $R_{f}$ is risk-free rate, $R_{m}$ is CRSP value-weighted market index return, $S M B$ is small-firm portfolio return minus big-firm portfolio return, $H M L$ is high book-to-market portfolio return minus low book-to-market portfolio return, and $W M L$ is past winner portfolio return minus past loser 
portfolio return, all measured at time $t$. The regression includes firms that have conducted IPOs in any of the past 1-year, 2-years, and 3-years respectively. Monthly returns begin one month after month of IPO issue date. Columns 1 (and 4) and 2 (and 5) in each panel show abnormal returns for Waiting period terciles 1 and 3 respectively while Column 3 (and 6) shows difference in abnormal returns between Waiting period terciles 1 and 3 by regressing the return difference between the two groups against the same factors. Months with less than five stocks in portfolio are excluded from regressions. t-statistics are reported in parentheses below the coefficients. Standard errors are adjusted based on White (1980). ${ }^{* * *} \mathrm{p}<0.01,{ }^{* *} \mathrm{p}<0.05,{ }^{*} \mathrm{p}<0.1$ 
Table 7. Waiting period and operating performance.

Panel A: Operating performance of IPOs with short and long waiting periods

\begin{tabular}{|c|c|c|c|c|c|c|c|c|}
\hline & \multicolumn{3}{|c|}{ Short waiting period } & \multicolumn{3}{|c|}{ Long waiting period } & \multirow[b]{2}{*}{$\begin{array}{c}\text { t-test (p- } \\
\text { value) }\end{array}$} & \multirow[b]{2}{*}{$\begin{array}{c}\text { rank sum test } \\
\text { (p-value) }\end{array}$} \\
\hline & $\mathrm{N}$ & Mean & Median & $\mathrm{N}$ & Mean & Median & & \\
\hline \multicolumn{9}{|c|}{ Operating Income before Depreciation/Assets (Return on Assets, ROA) } \\
\hline 1-year after IPO & 2326 & 0.0527 & 0.0749 & 2290 & 0.0006 & 0.0311 & $<0.0001$ & $<0.0001$ \\
\hline 2-years after IPO & 2205 & 0.0330 & 0.0534 & 2134 & -0.0203 & 0.0258 & $<0.0001$ & $<0.0001$ \\
\hline 3-years after IPO & 2017 & 0.0222 & 0.0437 & 1905 & -0.0389 & 0.0227 & $<0.0001$ & $<0.0001$ \\
\hline \multicolumn{9}{|c|}{ (Operating Income before Depreciation - Capital Expenditure)/Assets } \\
\hline 1-year after IPO & 2305 & -0.0308 & 0.0030 & 2268 & -0.0723 & -0.0301 & $<0.0001$ & $<0.0001$ \\
\hline 2-years after IPO & 2169 & -0.0600 & -0.0217 & 2110 & -0.1000 & -0.0460 & $<0.0001$ & $<0.0001$ \\
\hline 3-years after IPO & 1984 & -0.0560 & -0.0220 & 1884 & -0.1018 & -0.0361 & $<0.0001$ & $<0.0001$ \\
\hline \multicolumn{9}{|c|}{ Operating Income before Depreciation/Sales } \\
\hline 1-year after IPO & 2276 & -0.4499 & 0.0663 & 2234 & -0.8349 & 0.0377 & 0.0001 & $<0.0001$ \\
\hline 2-years after IPO & 2184 & -0.2981 & 0.0469 & 2085 & -0.4474 & 0.0291 & 0.0106 & $<0.0001$ \\
\hline 3-years after IPO & 2000 & -0.2772 & 0.0373 & 1867 & -0.5462 & 0.0249 & 0.0002 & $<0.0001$ \\
\hline \multicolumn{9}{|c|}{ (Operating Income before Depreciation - Capital Expenditure)/Sales } \\
\hline 1-year after IPO & 2257 & -0.8007 & 0.0057 & 2212 & -1.2910 & -0.0335 & 0.0002 & $<0.0001$ \\
\hline 2-years after IPO & 2150 & -0.6058 & -0.0206 & 2063 & -0.7875 & -0.0526 & 0.0304 & $<0.0001$ \\
\hline 3-years after IPO & 1969 & -0.4913 & -0.0198 & 1848 & -0.7984 & -0.0390 & 0.0007 & 0.0004 \\
\hline
\end{tabular}


Panel B: Impact of waiting period on ROA

(1)

Ln(Waiting period)
Underwriter rank
Ln(Capitalization)
Venture capital
Underpricing21
Ln(Amount offered)
Insider selling
Ln(1+Age)
CapEx/PPE
R\&D/Assets
Bubble
Crisis

$-0.0204 * * *$
$(-3.384)$
$0.0102 * * *$
$(5.471)$
$0.0138 * * *$
$(11.07)$
$-0.0307 * * *$
$(-5.241)$
$8.91 \mathrm{e}-05^{* *}$
$(2.159)$
$-0.0229 * * *$
$(-5.140)$
$0.00377 * * *$
$(5.137)$
$0.0424 * * *$
$(10.67)$
0.00460
$(0.320)$
$-0.604 * * *$
$(-12.23)$
$-0.0661 * * *$
$(-4.465)$
0.00181
$(0.0788)$
0.0131
$(0.499)$

(2)

$$
\begin{gathered}
-0.0299 * * * \\
(-4.027) \\
0.0104 * * * \\
(5.622) \\
0.0161^{* * *} \\
(6.443) \\
-0.0193 * * * \\
(-3.182) \\
0.000184 * * * \\
(5.325) \\
-0.0213 * * * \\
(-5.326) \\
0.00314 * * * \\
(4.757) \\
0.0369 * * * \\
(8.193) \\
0.0372 * * \\
(2.283) \\
-0.528 * * * \\
(-12.41) \\
-0.0635 * * * \\
(-2.916) \\
-0.0124 \\
(-0.698) \\
0.0246 \\
(1.088) \\
\end{gathered}
$$

2,681 0.486
(3)

$$
\begin{gathered}
-0.0276 * * * \\
(-3.558) \\
0.0119 * * * \\
(4.677) \\
0.0197 * * * \\
(7.388) \\
-0.0144 * * * \\
(-3.092) \\
0.000367 * * * \\
(5.327) \\
-0.0298 * * * \\
(-6.914) \\
0.00244 * * * \\
(3.857) \\
0.0383 * * * \\
(7.430) \\
0.0446 * * * \\
(3.104) \\
-0.554 * * * \\
(-12.48) \\
-0.103 * * * \\
(-3.269) \\
-0.0210 \\
(-1.084) \\
0.0163 \\
(0.504) \\
\end{gathered}
$$

Observations

2,838

0.510

R-squared

Notes: The sample includes completed IPOs from 1986-2011 after excluding unit offers, closed end funds, ADRs, spinoffs, reverse LBOs, financial firms (SIC code 6xxx), firms with offer price less than \$5, and firms that do not have CRSP share codes 10 or 11. All variables are defined in Appendix. Ln is natural logarithm. Panel A shows summary statistics using four measures of operating performance for 1-year, 2-years, and 3-years post-IPO. Short waiting period refers to firms with Waiting period less than that of the median. Long waiting period refers to firms with Waiting period greater than or equal to that of the median. Panel B shows results of OLS regressions using the first measure as the dependent variable computed over 1-year (Column 1), 2-years (Column 2), and 3-years (Column 3) post-IPO. t-statistics are reported in parentheses below the coefficients after adjusting for clustering within Fama and French (1997) industry. ${ }^{* * *} \mathrm{p}<0.01,{ }^{* *} \mathrm{p}<0.05,{ }^{*} \mathrm{p}<0.1$ 


\section{Appendix: Definition of variables}

All variables are obtained from Securities Data Corporation New Issue database (SDC) unless otherwise stated. All dollar values are adjusted for inflation using the GDP Implicit Price Deflator $(2010=100.00)$.

Age is difference in years between the year of the issue date and the founding year. We use the Field-Ritter data set of founding dates (Field and Karpoff 2002; Loughran and Ritter 2004), obtained from Professor Jay Ritter's website. The variable is winsorized at its 99\% value to reduce the effect of outliers.

Amendments is number of amendments filed from the filing date to the issue date. The variable is winsorized at its $99 \%$ value.

Amount offered is number of shares offered times offer price in millions of dollars.

Assets is total assets (Compustat mnemonic AT) in millions of dollars for fiscal year ending just prior to IPO. The variable is winsorized at its $1 \%$ and $99 \%$ values.

Auditor reputation equals one if external auditor (Compustat mnemonic AU) for fiscal year ending just prior to IPO has auditor code from 01 to 08 , and zero otherwise.

BHAR is buy-and-hold abnormal return and computed as follows:

$$
B H A R_{i, T}=\prod_{t=1}\left(1+R_{i, t}\right)-\prod_{t=1}\left(1+R_{\text {match }, t}\right)
$$

$R_{i, t}$ is daily net return for IPO firm $i$ at time $t$ and $R_{\text {match, } t}$ is daily net return for the matched firm at time $t$. The returns are measured from the first closing market price to the earlier of the anniversary (1-, 2-, or 3-years, as appropriate) or the delisting date.

Bubble equals one if issue date is from September 1998 to August 2000, and zero otherwise.

Bundle is number of firms (other than the firm in question, firm $i$ ) that the same lead underwriter simultaneously takes public between firm i's filing date and issue date. If there is more than one lead underwriter, the average is taken. The variable is winsorized at its $99 \%$ value.

CapEx/PPE is capital expenditures (Compustat mnemonic CAPX) divided by net property, plant, and equipment (Compustat mnemonic PPENT) for up to three fiscal years after IPO. The variable is winsorized at its $1 \%$ and $99 \%$ values.

Capitalization is measured in two ways. In Table 2, it is measured as number of shares outstanding from CRSP in millions for fiscal year ending just prior to IPO times midpoint of initial price range (i.e., average of low and high prices). In Table 7, it is measured as ordinary/common shares outstanding (Compustat mnemonic CSHO) in millions times closing stock price (Compustat mnemonic PRCC) for up to three fiscal years after IPO. Both measures are winsorized at their $1 \%$ and $99 \%$ values. 
Contemporaneous is number of firms in the same Fama and French (1997) industry that go public during the three weeks preceding and three weeks following firm i's filing date. The variable is winsorized at its $99 \%$ value.

Crisis equals one if year of issue date is 2008 or 2009, and zero otherwise.

Extreme price update equals one if offer price exceeds high of initial price range or offer price is less than low of initial price range each by more than $20 \%$, and zero otherwise.

Gross spread is percent of IPO proceeds paid to underwriters.

Hot IPO market is a dummy variable that equals one if a firm goes public in a hot IPO market as defined in Yung, Çolak, and Wei (2008), and zero otherwise. Specifically, IPOs are classified as "hot" by comparing the moving average MA(4) of the number of IPOs in each quarter with the historic average of the IPO activity in all previous quarters from 1975. If this moving average is $50 \%$ above the historical average, the quarter is classified as hot.

Industry return (90 days before filing) is equal weighted buy-and-hold industry return for 90 trading days ending one day before firm i's filing date. Industry is based on 48 industry classifications from Fama and French (1997) and industry returns are obtained from Professor Ken French’s website.

Industry return (filing to offer) is equal weighted buy-and-hold industry return between (but not including) firm i’s filing and offer dates.

Insider selling is number of secondary shares offered divided by CRSP number of shares outstanding after IPO times 100.

Lead/co-lead/co-managers is total number of lead, co-lead, and co-managers involved with taking the firm public. The variable is winsorized at its $99 \%$ value.

Long waiting period is measured in two ways. In Tables 5 and 7 , it refers to firms with Waiting period greater than or equal to that of the median. In Table 6, it refers to firms in Waiting period tercile 3.

NASDAQ equals one if IPO is listed on NASDAQ, and zero otherwise.

NYSE equals one if IPO is listed on New York Stock Exchange, and zero otherwise.

Operating Income before Depreciation/Assets is operating income before depreciation (Compustat mnemonic OIBDP) divided by total assets (Compustat mnemonic AT) for up to three fiscal years after IPO. The variable is winsorized at its $1 \%$ and $99 \%$ values.

(Operating Income before Depreciation - Capital Expenditure)/Assets is operating income before depreciation minus capital expenditures (Compustat mnemonic CAPX) all divided by total assets (Compustat mnemonic AT) for up to three fiscal years after IPO. The variable is winsorized at its $1 \%$ and $99 \%$ values. 
Operating Income before Depreciation/Sales is Operating income before depreciation (Compustat mnemonic OIBDP) divided by net sales/turnover (Compustat mnemonic SALE) for up to three fiscal years after IPO. The variable is winsorized at its $1 \%$ and $99 \%$ values.

(Operating Income before Depreciation - Capital Expenditure)/Sales is operating income before depreciation (Compustat mnemonic OIBDP) minus capital expenditures (Compustat mnemonic CAPX) all divided by net sales/turnover (Compustat mnemonic SALE) for up to three fiscal years after IPO. The variable is winsorized at its $1 \%$ and $99 \%$ values.

Pioneer equals one if there is no IPO initial filing in same Fama and French (1997) industry during 90 calendar days prior to firm i’s filing, and zero otherwise.

Positive EPS dummy equals one if earnings per share (diluted) excluding extraordinary items (Compustat mnemonic EPSFX) for fiscal year ending just prior to IPO is greater than zero, and zero otherwise.

Post-IPO return volatility is market model (using CRSP value-weighted index and CRSP stock returns) root-mean-square error for the following four periods (based on trading days) after the IPO:- +21 to +79 ; +21 to +142 ; +21 to +205 ; +21 to +268 . The variable is winsorized at its $1 \%$ and $99 \%$ values.

Price update is offer price minus midpoint of initial price range all divided by midpoint of initial price range times 100 .

$R \& D /$ Assets is research and development expenses (Compustat mnemonic XRD) divided by total assets (Compustat mnemonic AT) for up to three fiscal years after IPO. The variable is winsorized at its $1 \%$ and $99 \%$ values.

Short waiting period is measured in two ways. In Tables 5 and 7, it refers to firms with Waiting period less than that of the median. In Table 6, it refers to firms in Waiting period tercile 1.

Small capitalization equals one if bottom tercile of Capitalization (based on the Table 2 measure), and zero otherwise.

SOX equals one if year of IPO issue date is 2002 or later, and zero otherwise.

Std. Dev. of EPS forecasts is most recently available standard deviation of forecasts of annual one-year-ahead EPS during a particular period (i.e., 90-, 180-, 270-, or 360-calendar days following IPO) scaled by the absolute value of the mean EPS forecast on the same date. The variable is winsorized at its $1 \%$ and $99 \%$ values.

Std. Dev. of industry return (90 days before filing) is standard deviation of equal weighted daily industry returns for 90 trading days ending one day before firm $i$ 's filing date.

Std. Dev. of industry return (filing to offer) is standard deviation of equal weighted daily industry returns between (but not including) firm i’s filing and offer dates. 
Std. Dev. of long-term growth forecasts is most recently available standard deviation of operating earnings long-term growth forecasts from I/B/E/S during a particular period (i.e., 90-, 180-, 270-, or 360-calendar days following IPO). The variable is winsorized at its $1 \%$ and $99 \%$ values.

Technology equals one if firm is in technology industry as defined in Loughran and Ritter (2004), and zero otherwise. Specifically, technology firms are those with SIC codes 3571, 3572, 3575, 3577, 3578 (computer hardware), 3661, 3663, 3669 (communications equipment), 3671, 3672, 3674, 3675, 3677, 3678, 3679 (electronics), 3812 (navigation equipment), 3823, 3825, 3826, 3827, 3829 (measuring and controlling devices), 3841, 3845 (medical instruments), 4812, 4813 (telephone equipment), 4899 (communications services), and 7371, 7372, 7373, 7374, 7375, 7378, 7379 (software).

Underpricing 1 is closing stock price on $1^{\text {st }}$ day of trading minus offer price all divided by offer price times 100 . The closing stock price is from CRSP. The variable is winsorized at its $1 \%$ and $99 \%$ values.

Underpricing 21 is closing stock price on $21^{\text {st }}$ day of trading minus offer price all divided by offer price times 100. The closing stock price is from CRSP. The variable is winsorized at its $1 \%$ and $99 \%$ values.

Underwriter rank is ranking of lead underwriter based on Carter and Manaster (1990) ranking, updated on Professor Jay Ritter's website, and described in Loughran and Ritter (2004). If there is more than one lead underwriter, the average rank is taken.

Venture capital equals one if firm is backed by a venture capitalist, and zero otherwise.

Waiting period is number of calendar days from filing date to issue date. The variable is winsorized at its $99 \%$ value.

Waiting period dummy equals one for firms in Waiting period tercile 3 and zero for firms in Waiting period tercile 1.

Withdrawn/Postponed is number of withdrawn or postponed IPOs during 90 calendar days prior to firm i's filing date. The variable is winsorized at its $99 \%$ value. 